Florida International University FIU Digital Commons

6-17-2014

\title{
Genetic Diversity and Conservation of Pseudophoenix (Arecaceae) in Hispaniola
}

Rosa Rodriguez

Florida International University, rrodr419@fiu.edu

DOI: $10.25148 /$ etd.FI14071182

Follow this and additional works at: https://digitalcommons.fiu.edu/etd

\section{Recommended Citation}

Rodriguez, Rosa, "Genetic Diversity and Conservation of Pseudophoenix (Arecaceae) in Hispaniola" (2014). FIU Electronic Theses and Dissertations. 1554.

https://digitalcommons.fiu.edu/etd/1554 


\title{
FLORIDA INTERNATIONAL UNIVERSITY
}

Miami, Florida

\section{GENETIC DIVERSITY AND CONSERVATION OF PSEUDOPHOENIX (ARECACEAE) IN HISPANIOLA}

\author{
A thesis submitted in partial fulfillment of the \\ requirements for the degree of \\ MASTER OF SCIENCE \\ in \\ BIOLOGY \\ by
}

Rosa Rodriguez

2014 
To: Dean Kenneth G. Furton

College of Arts and Sciences

This thesis, written by Rosa Rodriguez, and entitled Genetic Diversity and Conservation of Pseudophoenix (Arecaceae) in Hispaniola, having been approved in respect to style and intellectual content, is referred to you for judgment.

We have read this thesis and recommend that it be approved.

Jennifer Richards

Scott Zona

Brett Jestrow

Javier Francisco-Ortega, Major Professor

Date of Defense: June 17, 2014

The thesis of Rosa Rodriguez is approved.

\begin{tabular}{r} 
Dean Kenneth G. Furton \\
College of Arts and Sciences \\
\hline Dean Lakshmi N. Reddi \\
University Graduate School
\end{tabular}

Florida International University, 2014 


\section{ACKNOWLEDGMENTS}

I would like to thank the Fulbright-LASPAU program in the Dominican Republic for giving me the amazing opportunity to come to the USA to improve my English skills and to enroll in a Master's degree program. Research was primarily supported by the Mohamed bin Zayed Species Conservation Fund (project numbers 11252872 and 12254927) and matching research funds from Fairchild Tropical Botanic Garden. Additional support was provided by the International Palm Society, and the Montgomery Botanical Center. Florida International University provided matriculation waiver. I would like to thank the National Botanical Garden of Santo Domingo (Dominican Republic), for helping to organize field trips in the Dominican Republic. I specially would like to thanks Teodoro Clase, who accompany me to all my field trips in the Dominican Republic. Dr. Liz Harrison, Dr. Alan Meerow, and Dr. Nora Oleas helped with the data analyses. Mr. Daniel Gann and Dr. Paul Sharp provided help with the preparation of maps and DNA protocols, respectively. Professor Gren Draper provided valuable insights pertinent to the geology of Hispaniola. My gratitude to William Cinea (Haiti), Arlington James (Dominica), Bryan N. Manco (Turks and Caicos), José Justache-Justache (Puerto Rico), and Eugenio Santiago-Valentín (Puerto Rico) for providing plant material and relevant information pertinent to the conservation status of populations from outside the Dominican Republic. Last but not least, I would like to thank my graduate committee, Dr. Javier Francisco-Ortega, Dr. Jennifer Richards, Dr. Scott Zona, and Dr. Brett Jestrow for their support, advice, and all their patience during this process. 


\author{
ABSTRACT OF THE THESIS \\ CONSERVATION AND GENETIC DIVERSITY OF PSEUDOPHOENIX \\ (ARECACEAE) IN HISPANIOLA \\ by \\ Rosa Rodriguez \\ Florida International University, 2014 \\ Miami, Florida \\ Professor Javier Francisco-Ortega, Major Professor
}

The Caribbean genus Pseudophoenix (Arecaceae) has its center of taxonomic diversity in Hispaniola (Haiti and the Dominican Republic). Three species (P. ekmanii, P. lediniana, and $P$. vinifera) are restricted to this island. In this thesis I investigated the population genetic diversity and structure of Pseudophoenix using ten microsatellite loci. Results showed homozygote excess and high inbreeding coefficients in all populations across all polymorphic loci. Overall, there was high differentiation among populations. Results from the Bayesian and Neighbor Joining cluster analyses identified groups that were consistence with currently accepted species delimitation. We included the only known population of an undescribed morph from the Dominican Republic that has been suggested to represent a new species. Results from the cluster analyses suggested that this putative species is closely related to $P$. sargentii from Turk and Caicos. Our study provided insights pertinent to the conservation genetics and management of this genus in Hispaniola. 


\section{TABLE OF CONTENTS}

CHAPTER

PAGE

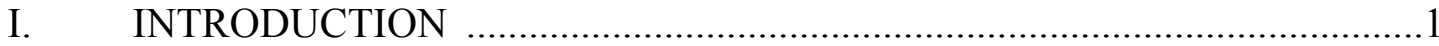

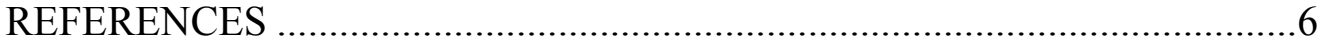

II. CONSERVATION AND GENETICS OF TWO CRITICALLY

ENDANGERED HISPANIOLAN PALMS - GENETIC EROSION OF

PSEUDOPHOENIX LEDINIANA IN CONTRAST TO P. EKMANII ............10

MATERIALS AND METHODS...........................................................13

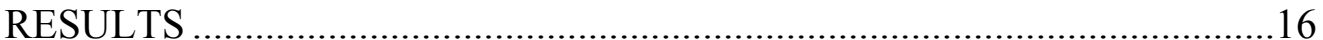

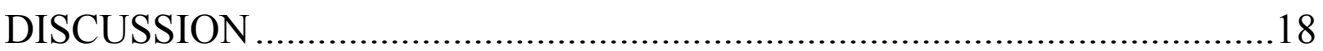

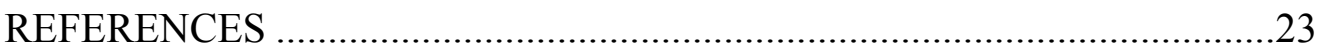

III. GENETIC DIVERSITY AND DIFFERENTIATION OF PSEUDOPHOENIX (ARECACEAE) IN HISPANIOLA …………................34

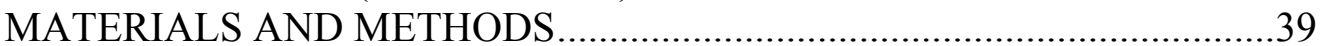

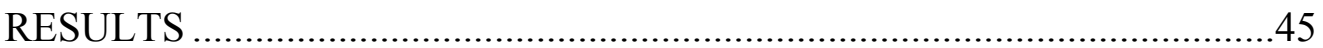

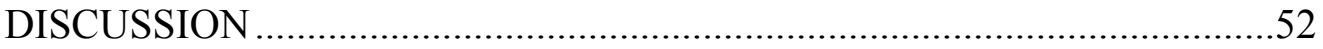

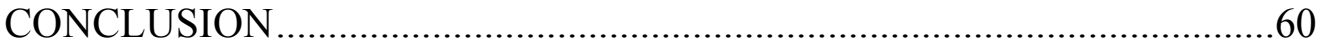

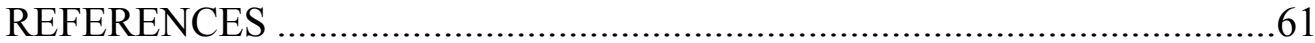


1.1. The Caribbean Island Biodiversity Hotspot.............................................................

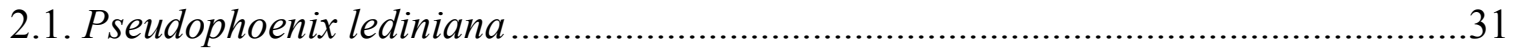

2.2. Distribution of Pseudophoenix lediniana on Haiti, showing the spatial fragmented

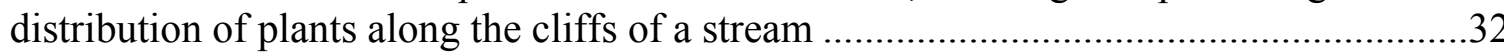

2.3. Principal coordinate and STRUCTURE $(\mathrm{K}=2)$ analyses of DNA microsatellite data for the only known population of Pseudophoenix lediniana ....................................33

3.1. Pseudophoenix plants in Dominican Republic .......................................................68

3.2. Pseudophoenix plants in Dominican Republic and Haiti ..........................................69

3.3. Geographical distribution of the 18 populations of Pseudophoenix included in this study

3.4. Principal coordinate analysis scatter diagram along the two first coordinates

3.5. Neighbor joining network (based on chord distance of Cavalli-Scorza and Edwards (1967). 


\section{INTRODUCTION}

\section{CONCEPTUAL FRAMEWORK}

The Caribbean Island Biodiversity Hotspot (Fig. 1.1) is one of the world hotspots with the highest probability for extinction of endemic plants and vertebrates as a consequence of the negative impact of deforestation (Brooks et al. 2002; Mittermeier et al. 2004). In addition, Shi et al. (2005) indicated that the Caribbean Hotspot is one of the four hotspots with the highest pressure from human activities. Therefore, it is not surprising that $39 \%$ of the Caribbean palms are threatened by extinction (Zona et al. 2007).

Pseudophoenix H. Wendl. ex Sarg. (Arecaceae) is the sole genus in the tribe Cyclospathe O. F. Cook, subfamily Ceroxyloideae Drude. As such, it is an isolated lineage with no close relatives within the palm family (Dransfield et al. 2008). The four currently recognized species (Zona 2002) occur in the Lesser Antilles (only Dominica), Greater Antilles [Cuba, Navassa Island (USA territory), Hispaniola, and Puerto Rico (island of Mona)], southern Florida, USA (a few islets in Biscayne National Park), the Bahamas, Turk and Caicos Islands, and the Yucatan Peninsula (both Mexico and Belize). The species generally occur in seasonally dry forest or coastal scrub (Zona 2002).

The genus was the subject of a modern taxonomic revision by Zona (2002), and his revision provides the taxonomy that is followed herein. The island of Hispaniola is the center of highest taxonomic diversity with three endemic species (i.e., P. ekmanii Burret, $P$. lediniana Read, and P. vinifera (Mart.) Becc.) and one native, P. sargentii $\mathrm{H}$. Wendl. ex Sargent. Pseudophoenix sargentii is widespread within the area where the genus is found, although it is rare in Hispaniola, Florida, Puerto Rico, and Cuba (Zona 
2002). Zona (2002) noted a single specimen of Pseudophoenix from northern Dominican Republic that he was unable to assign to species on the basis of comparative morphology. The single specimen was a tantalizing suggestion that additional morphological diversity exists in the Dominican Republic. The unique morph (thereafter Pseudophoenix sp. nova) has an unusual ecology, as it is the only species of the genus to thrive on serpentine soils, which are soils characterized by high nickel and magnesium content.

Population genetic studies are widely accepted as providing important perspectives for conservation, allowing biologists to assess the genetic diversity of species and to establish conservation management strategies (Allendorf and Luikart 2007; Höglund 2009). Conservation genetic studies follow the assumption that habitat changes can influence both extinction risks and three population genetic components: (1) genetic drift, because of stochastic changes in allele frequencies; (2) gene flow, because of the disruption of migration barriers; and (3) the frequency of alleles with adaptive value (Frankham et al. 2004). Therefore, a major paradigm in conservation genetics is that habitat degradation results in loss of genetic variation (Young et al. 1996), as measured by population genetic parameters such as allelic richness and heterozygosity levels (e.g., Van Treuren et al. 1991; Young et al. 1999). Inbreeding increases homozygosity and, as a consequence, the frequency of homozygotes exposing deleterious alleles (e.g., Raijmann et al. 1994). Moreover, when the habitat is fragmented, populations lose their connectivity, and gene flow is interrupted (e.g., Hickerson and Wolf 1998). In addition, fitness - the capability of an individual to survive and reproduce during its life - is expected to decline when population size decreases because of the negative effects of genetic drift and inbreeding (Reed and Frankham 2003). When genetic diversity 
decreases many alleles with adaptive value are likely to be lost because of stochastic events (Reed and Frankham 2003; Leimu et al. 2006). As a consequence, it has been postulated that loss of genetic diversity is detrimental to the ability of populations to adapt, making them more susceptible to environmental changes (Palstra and Ruzzante 2008).

Although population genetic models clearly show the negative relationship between habitat fragmentation and genetic diversity (Herron and Freeman 2013), the extent to which habitat fragmentation always results in reduced population genetic diversity is still controversial. For instance, Honnay and Jacquemyn (2007) found a positive correlation between genetic diversity and population size among different studies for 52 plant species. However, other studies have found negative relationships between these two factors. Greimler and Dobes (2000) described this relationship for Gentianella austriaca (A. Kern. \& Jos. Kern.) Holub (Gentianaceae). They compared the genetic diversity of populations of different sizes and found that in some cases smaller populations have higher genetic diversity than larger ones.

Because conservation genetic studies can provide important instruments for conservation, they are clearly applicable for organisms found in Biodiversity Hotspots. The Caribbean Island Biodiversity Hotspot has a high number of endemic plant species and therefore many plant conservation challenges (Maunder et al. 2008). As noted by Geiger et al. (2014), few population genetic studies have been conducted in these islands. Eight of these studies have used nuclear DNA microsatellite data (SSRs) to document the genetic structure and diversity of Caribbean plants. They focused on Ipomoea microdactyla Griseb. (Convolvulaceae) (Geiger et al. 2014), Pinus caribaea Morelet var. 
bahamensis (Griseb.) W. H. Barrett \& Golfari (Pinaceae) (Sanchez et al. 2014), Pterocarpus officinalis Jacq. (Fabaceae) (Muller et al. 2009), Pseudophoenix ekmanii (Namoff et al. 2011), Zamia lucayana Britton (Zamiaceae) (Calonje et al. 2013), and Z. pumila L. (Meerow et al. 2012).

The principal objective of the present thesis was to investigate the population genetic structure of the four species of Pseudophoenix that occur in Hispaniola. Additionally, we aimed to explore its relationship with patterns of geographical distribution and morphological differentiation as understood by the currently accepted taxonomy (Zona 2009). The three main working hypotheses are:

H1: Patterns of genetic diversity will reflect the taxonomy proposed by Zona (2002). Therefore, populations belonging to the same species will form discrete and distinct clusters.

H2: Within each species, genetic distances within populations will be related to geographical distances, i.e., geographically close populations will be genetically close as well.

H3: A positive correlation will exist between population size and genetic diversity. Therefore, fragmented or reduced populations found in unprotected areas with high human impact will have lower levels of genetic diversity.

This thesis is presented in three chapters. Chapter 1 provides a general introduction to the genus Pseudophoenix and a conceptual framework of the importance of population genetic studies to address conservation biology projects. The second chapter, "Conservation and genetics of two critically endangered Hispaniolan palms genetic erosion of Pseudophoenix lediniana and high genetic diversity P. ekmanii" has 
been accepted for publication in the peer-reviewed journal Plant Systematics and Evolution. It addresses main conservation biology issues of $P$. lediniana. The species is the most Critically Endangered (sensu IUCN 2013) species of the genus (approximately 70 plants without recruitment are known in a single population in southern Haiti). The second chapter is primarily derived from exhaustive field work to determine distribution patterns and conservation threats to the taxon. Also, a comparison between P. lediniana and P. ekmanii of levels of genetic variation based on microsatellite (SSR) data is provided. The latter species is also Critically Endangered but it is officially protected in a national park, where at least four populations are known. Previous demographic estimates suggest that these four populations harbor approximately 3,800 adult individuals. For the second chapter population genetic statistical data pertinent to $P$. ekmanii came from a previous conservation genetic study published by Namoff (2011). The third chapter provides a full genetic diversity study for all the species of Pseudophoenix occurring in Hispaniola. Additionally, three populations of $P$. sargentii (found in Puerto Rico [Mona Island], Dominica and the Turk and Caicos) were included in work in chapter three. They represent outliers that provide a sampling framework to improve understanding of the genetic relationships among the species and populations from Hispaniola. 


\section{REFERENCES}

Allendorf FW, Luikart G (2007) Conservation and the genetics of populations. Blackwell, Malden

Brooks TM, Mittermeier RA, Mittermeier CG, da Fonseca GAB, Rylands AB, Konstant WR, Flick P, Pilgrim J, Oldfield S, Magin G, Hilton-Taylor C (2002) Habitat loss and extinction in the hotspots of biodiversity. Conservation Biol 16:909-923

Calonje M, Meerow AW, Knowles L, Knowles D, Griffith P, Nakamura K, FranciscoOrtega J (2013) Cycad biodiversity in the Bahama Archipelago and conservation genetics of the Critically Endangered Zamia lucayana (Zamiaceae). Oryx 47:190198

Dransfield J, Uhl N, Asmussen C, Baker WJ, Harley M, Lewis C (2008) Genera Palmarum. The evolution and classification of palms. Kew Publishing, Royal Botanic Gardens Kew

Frankham R, Ballou JD, Briscoe DA (2004) A primer in conservation genetics. Cambridge University Press, Cambridge.

Geiger JH, Meerow AW, Lewis C, Oviedo R, Francisco-Ortega J (2014) Genetic diversity and conservation of Ipomoea microdactyla (Convolvulaceae): an endemic vine from the Bahamas, Cuba, and southeastern Florida. Pl Spec Biol $29: 2-15$

Greimler J, Dobes C (2000) High genetic diversity and differentiation in relict lowland populations of Gentianella austriaca (A. and J. Kern.) Holub (Gentianaceae). Pl Biol 2:628-637

Herron JC, Freeman S (2013) Evolutionary analysis. 5th ed. Benjamin Cummings

Hickerson LL, Wolf PG (1998) Population genetic structure of Arctomecon californica Torrey \& Fremont (Papaveraceae) in fragmented and unfragmented habitat. Pl Spec Biol 13:21-33

Höglund J (2009) Evolutionary conservation genetics. Oxford University Press, Oxford

Honnay O, Jacquemyn H (2007) Susceptibility of common and rare plant species to the genetic consequences of habitat fragmentation. Conservation Biol 21:823-831

IUCN (2013) The IUCN red list of threatened species. Version 2013.1. http://www.iucnredlist.org/ 
Leimu R, Mutikainen P, Koricheva J, Fischer M (2006) How general are positive relationships between plant size, fitness and genetic variation? population. J Ecol 94:942-952

Maunder M, Leiva A, Santiago-Valentín E, Stevenson DW, Acevedo-Rodríguez P, Meerow AW, Mejía M, Clubbe C, Francisco-Ortega J (2008) Plant conservation in the Caribbean Island biodiversity hotspot. Bot Rev 74:197-207

Meerow AW, Francisco-Ortega J, Calonje M, Griffith MP, Ayala-Silva T, Stevenson DW, Nakamura K (2012) Zamia (Cycadales: Zamiaceae) on Puerto Rico: asymmetric genetic differentiation and the hypothesis of multiple introductions. Amer J Bot 99:1828-1839

Mittermeier RA, Robles Gil R, Hoffman M, Pilgrim J, Brooks T, Mittermeier CG, Lamoreux J, da Fonseca GAB eds (2004) Hotspots revisited: Earth's biologically richest and most threatened terrestrial ecoregions. CEMEX, Mexico DF

Muller F, Voccia M, Bâ A, Bouvet JM (2009) Genetic diversity and gene flow in a Caribbean tree Pterocarpus officinalis Jacq.: a study based on chloroplast and nuclear microsatellites. Genetica 135:185-198

Namoff S, Veloz A, Jiménez F, Rodríguez-Peña RA, Peguero B, Lewis C, Moynihan J, Abdo M, Maunder M, Meerow A, Von Wettberg E, Griffith P, Francisco-Ortega J (2011) Sweet drinks are made of this: conservation genetics of an endemic palm species from the Dominican Republic. J Heredity 102:1-10

Palstra FP, Ruzzante DE (2008) Genetic estimates of contemporary effective population size: what can they tell us about the importance of genetic stochasticity for wild population persistence? Molec Ecol 17:3428-3447

Raijmann LEL, Van Leeuwen NC, Kersten R, Oostermeijer G, Den Nijs HCM, Menken SBJ (1994) Genetic variation and outcrossing rate in relation to population size in Gentiana pneumonanthe L. Conservation Biol 8:1014-1026

Reed DH, Frankham R (2003) Correlation between fitness and genetic diversity. Conservation Biol 17:230-237

Sanchez M, Ingrouille MJ, Cowan RS, Hamilton MA, Fay MF (2014) Spatial structure and genetic diversity of natural populations of the Caribbean pine, Pinus caribaea var. bahamensis (Pinaceae), in the Bahaman archipelago. Bot J Linn Soc 174:359-383

Shi H, Singh A, Kant S, Zhu Z, Waller E (2005) Integrating habitat status, human population pressure, and protection status into biodiversity conservation priority setting. Conservation Biol 19:1273-1285 
Van Treuren R, Bijlsma R, Van Delden W, Ouborgi NJ (1991) The significance of genetic erosion in the process of extinction . I . Genetic differentiation in Salvia pratensis and Scabiosa columbaria in relation to population size. Heredity 66:181-189

Young A, Boyle T, Brown T (1996) The population genetic consequences of habitat fragmentation for plants. Trends Ecol Evol 11:413-418

Young AG, Brown AHD, Zich FA (1999) Genetic structure of fragmented populations of the endangered daisy Rutidosis leptorrhynchoides. Conservation Biol 13:256265

Zona S (2002) A revision of Pseudophoenix. Palms 46:19-37

Zona S, Verdecia R, Leiva Sánchez A, Lewis CE, Maunder M (2007) The conservation status of West Indian palms (Arecaceae). Oryx 41:300-305 


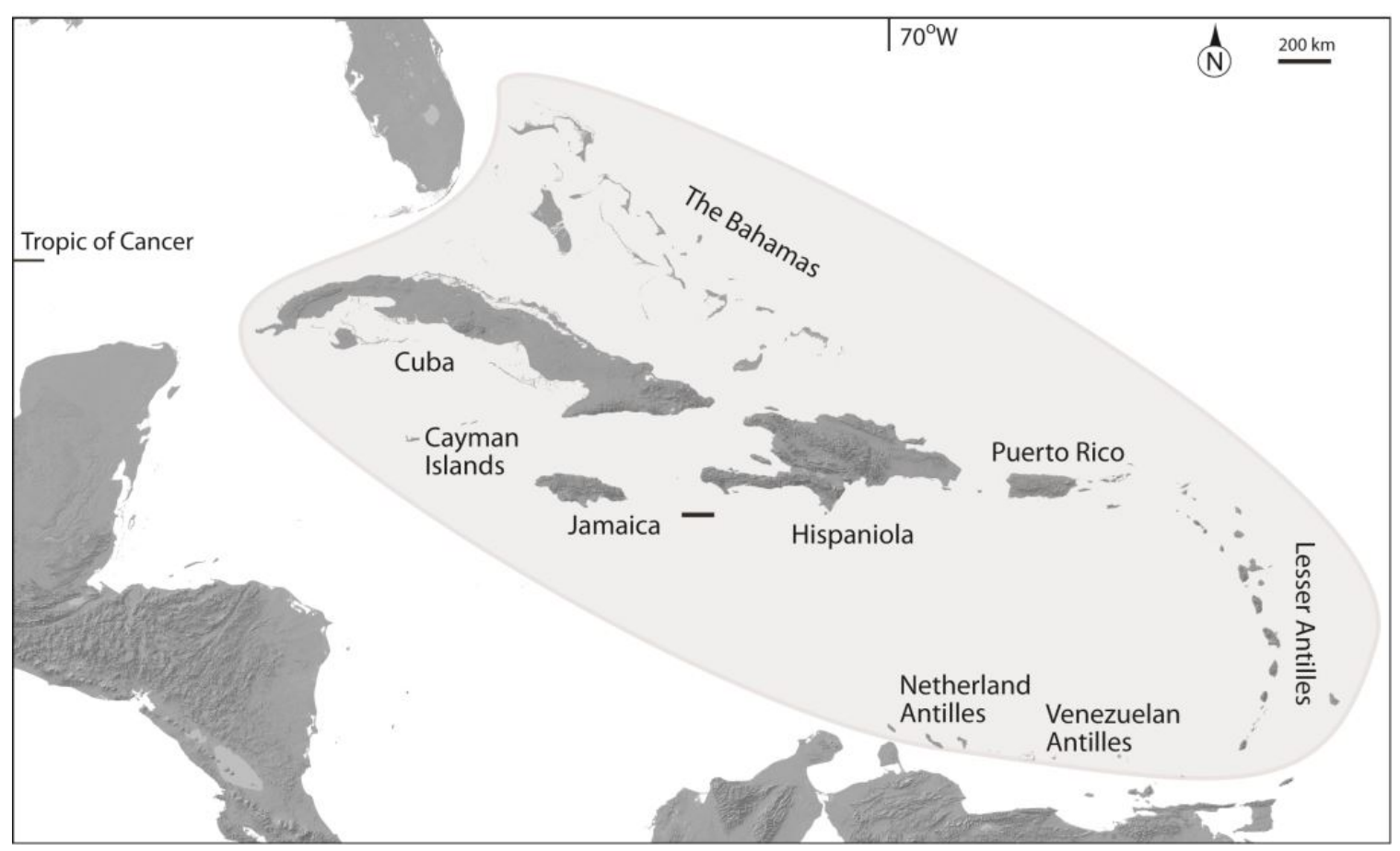

Fig 1.1. The Caribbean Island Biodiversity Hotspot. 


\section{CHAPTER II. CONSERVATION AND GENETICS OF TWO CRITICALLY ENDANGERED HISPANIOLAN PALMS - GENETIC EROSION OF PSEUDOPHOENIX LEDINIANA IN CONTRAST TO P. EKMANII}

The flora and fauna of Haiti, part of the Caribbean Island Biodiversity Hotspot, are recognized as a global priority for conservation (Smith et al. 2004; Maunder et al. 2008), characterized by both high levels of endemism and high levels of threat. Currently only $2 \%$ of the land is covered with natural forest compared with a $60 \%$ coverage in the 1920s (Fox 2012). The high rate of deforestation has resulted in massive soil erosion and associated declines in ecosystem services and biodiversity (Paryski et al. 1989; Paskett and Philoctete 1990; Sergile and Woods 2001). On the basis of preliminary studies led by the National Botanic Garden (Dominican Republic), Haiti is estimated to have over 467 endemic species of angiosperms (Clase and Peguero 2006). The flora of the country has not been comprehensively assessed using IUCN Categories of Threat (IUCN 2013) and the conservation status of many of the endemics is unknown.

In the last six years a consortium of Caribbean and US scientists has been studying the conservation status of the Caribbean flora (Francisco-Ortega et al. 2007; Maunder et al. 2008; Oleas et al. 2013; Carey et al. in press), using molecular techniques to address conservation questions (e.g., Meerow and Nakamura 2007; Namoff et al. 2011; Meerow et al. 2012; Calonje et al. 2013; Geiger et al. 2014). The consortium has also conducted molecular phylogenetic research relevant to the taxonomy and management strategies of Caribbean Endangered and Critically Endangered plant species (reviewed in Oleas et al. 2013).

Palms illustrate many of the conservation challenges facing island-endemic plants (Johnson 1996; Heywood 2011) of the Caribbean and in particular those of Haiti (Zona et 
al. 2007). It is estimated that $58 \%$ of palm species are restricted to islands (Morici 2004). Island endemic palms have suffered a long history of anthropogenic decline. There is good evidence that human activities have been responsible for most of the extinctions of palms of the Pacific Islands during the late Quaternary (Prebble and Dowe 2008;

Cañellas-Boltà et al. 2013). Major conservation threats for island palms include invasive species (Strahm 1996; Fleischmann et al. 2005; Meyer and Butaud 2009), unsustainable use (Read 1988; Ratsirarson et al. 1996; Rueger and von Wallmenich 1996; Morrison et al. 2012), habitat clearance (Dowe et al. 1997; Maunder et al. 2002; Shapcott et al. 2007; Manohara et al. 2010), and potentially the impact of climatic change (Shapcott et al. 2012a). A variety of approaches have been developed to recover threatened island palm populations including ecological restoration and species reintroduction (Maschinski and Duquesnel 2006), ex situ conservation (Namoff et al. 2010b), sustainable harvesting (Rist et al. 2010; Francisco-Ortega and Zona 2013), development of species recovery plans (Morrison et al. 2012), and invasive alien species control (Auld et al. 2010). The government of the Dominican Republic has established a reserve ("Monumento Natural Los Cacheos") near the border with Haiti to provide official protection to Pseudophoenix vinifera (Mart.) Becc. (Arecaceae) (Sectorial Law Number 202-04 for Protected Areas), specifically to prevent sap tapping, horticulture poaching, and to protect the palm's natural habitat (Congreso Nacional de la República Dominicana 2004).

Approximately seven species of palms are endemic to Hispaniola with three of these found only in Haiti (i.e., Attalea crassispatha (Mart.) Burret, Copernicia ekmanii Burret, and Pseudophoenix lediniana Read) (Henderson et al. 1990; 1995). Henderson et al. (1990) presented a review of the conservation status of Haitian palms, in large part 
derived from fieldwork performed between 1988 and 1989. He reported that the endemic Copernicia ekmanii (Endangered sensu IUCN (2013)) was restricted to a single site with only one surviving individual. Subsequent extensive fieldwork organized by Fairchild Tropical Botanic Garden botanists in 1996 showed that the species, although locally restricted to coastal areas of northern Haiti, is more abundant with at least 1,200 individuals recorded within its limited distribution range (Timyan et al. 1997; Johnson 1998).

The second Haitian endemic palm, Attalea crassispatha, (Critically Endangered sensu IUCN (2013)), is confined to two areas in the south of the country. Field surveys performed by Timyan and Reep (1994) in the early 1990s indicated that, although the distribution range of the species is relatively large (11 sites) there were only 25 individuals known in the wild. The 1990s survey led to ex situ conservation initiatives. Currently a total of ten individuals are cultivated at Montgomery Botanical Center, 35 at Fairchild Tropical Botanic Garden and 14 at the Tropical Research and Education Center of the University of Florida. While there are more individuals in cultivation than in the wild, the level of founder representation in the ex situ populations is unknown.

Three out of the four known species of Pseudophoenix are endemic to Hispaniola. Pseudophoenix ekmanii Burret (Critically Endangered) is a restricted to southwestern Dominican Republic, (Namoff et al. 2011). Pseudophoenix lediniana (Critically Endangered) is confined to southern Haiti. Pseudophoenix vinifera (Vulnerable sensu IUCN (2013)) is found both in Haiti and the Dominican Republic (Zona 2002). The fourth, $P$. sargentii, is not globally threatened, with a relatively wide distribution range in the Caribbean Basin (the Bahamas, Dominica, Florida Keys, Greater Antilles, and 
Yucatan Peninsula). However, many populations of the species are small and threatened on offshore islands (Zanoni and Buck 1999; Zona 2002; Maschinski and Duquesnel 2006; Santiago-Valentín et al. 2012). Both P. ekmanii and P. vinifera appear to be threatened by the unsustainable harvesting of sap in the Dominican Republic to make a non-alcoholic beverage known as "Mabí de Cacheo", few of the individuals survive the tapping process (Francisco-Ortega and Zona 2013).

Pseudophoenix lediniana, previously reported a wild population size of about 30 individuals, and is known from one site in southern Haiti, near Jacmel in the Province of Ouest (Henderson et al. 1990) where it is restricted to the slopes of the Rivière Lavange near the epicenter of the 2010 earthquake. From these previous accounts the species was known to grow on unstable mostly inaccessible steep cliffs and that the individuals of this palm were difficult to reach.

The present study was initiated to confirm that $P$. lediniana still occurred in the wild, with the objectives of mapping its current distribution area and to prepare conservation proposals. A second objective was to obtain DNA samples for a conservation genetic study to determine the levels of genetic diversity of this species when compared with the congeneric Dominican Republic endemic P. ekmanii (Namoff et al. 2011).

\section{MATERIALS AND METHODS}

\section{COLLECTING SITE AND DEMOGRAPHIC STUDIES}

Between November 2012 and July 2013 three of the authors (AV, BJ, and WC) made three visits to the area where the species was previously known to occur in the 
Province of Ouest. Other localities near the reported population were visited but additional individuals of $P$. lediniana were not located.

During fieldwork several difficulties were faced as most of the individuals were growing on inaccessible sites with unstable substrates; therefore, exhaustive surveys were conducted only in one third of the area where the species occurs. For the rest of the population, the demographic estimates were derived from observations performed with binoculars by two of the team members independently. The number of individuals were counted for adults (i.e., reproductively mature, generally taller than $2 \mathrm{~m}$ ), juveniles (not yet reproductively mature, generally less than $2 \mathrm{~m}$ ), and seedlings (plants with no visible trunk, usually with only two emerging small leaves). The number of individuals that were flowering or fruiting was also recorded. The GPS points of plant localities were recorded. MICROSATELLITE DNA ANALYSIS

Seven DNA microsatellite loci (i.e., pse2.1, pse3.33, pse3.6, pse5.2, pse5.5, pse5.6, and pse7.26) were used to investigate the patterns of genetic diversity of $P$. lediniana. These were the same variable markers that were utilized in a previous conservation genetic study of $P$. ekmanii (Namoff et al. 2011). The DNA was isolated from leaf fragments (fast-dried in silica gel) following Namoff et al. (2010a, 2011). Procedures for PCR amplification and visualization of microsatellite fragments (SSRs) also follow Namoff et al. (2010a, 2011). Fragments were separated using an ABI 3130XL Genetic Analyzer (Applied Biosystems) in the DNA core facility of Florida International University (FIU). Subsequently, alleles were visualized and scored using Peak-Scanner (Applied Biosystems). A total of 21 individuals were sampled encompassing approximately one third of the known wild individuals (see further details pertinent to the 
special distribution of individuals below). The program Micro-Checker (Van Oosterhout et al. 2004) was used to evaluate the presence of null alleles and allelic dropouts, employing 10,000 randomizations. Descriptive statistics were obtained with GenAlEx v. 6.501 (Peakall and Smouse 2006, 2012). Tests for Hardy-Weinberg equilibrium (HWE) and the U test (Rousset and Raymond 1995) for heterozygote excess or deficiency were run with GenePop v. 4.0 (Raymond and Rousset 1995; Rousset 2008) using 10,000 Markov chain Monte Carlo iterations (Guo and Thompson 1992). Linkage disequilibrium (LD) was tested for each population with ARLEQUIN v. 3.5 (Excoffier et al. 2005) using a likelihood ratio test (Slatkin and Excoffier 1996). A Markov chain Monte Carlo method was applied with 100,000 iterations and a burn-in of 10,000. Inbreeding coefficients (Fis) were calculated for each population using FSTAT (Goudet 1995). The significance of deviations of Fis from 0 was accessed by permutation tests ( 1000 permutations with 0.05 alpha level for Bonferroni correction). These calculations were also performed with FSTAT. Principal coordinate analysis (PCO) among all the individuals included in the study was computed with GenAlEx that uses the algorithm developed by Orloci (1978), after conversion of the individual-by-individual genetic distance matrix, as defined by Smouse and Peakall (1999), to a covariance matrix and data standardization. The Bayesian clustering program STRUCTURE v.2.3.3 (Pritchard et al. 2000) was used to estimate the underlying genetic structure among the two population sites. The K-values of $1-5$ were simulated across 20 replicate runs of 1,000,000 iterations after a burn-in of 100,000. The $\Delta \mathrm{K}$ method of Evanno et al. (2005) as implemented in STRUCTURE HARVESTER (Earl 2011) was used for determining the 'true' value of $\mathrm{K}$ across the samples. After the likely level of $\mathrm{K}$ was estimated, a consensus Q-matrix from the 20 
runs was constructed using the program CLUMPP (Jakobsson and Rosenberg 2007) for visualization with DISTRUCT (Rosenberg 2004).

\section{RESULTS}

\section{FIELD STATUS}

Field studies verified the presence of $P$. lediniana in the area where the species was originally described (Fig. 2.1). Only 71 adults and 2 juveniles were recorded, with no seedlings observed during our flied campaigns. Just a single tree produced fruits in 2013 (Fig. 2.1). In 2012 the dry remains of a fruiting branch was also found in a single tree. The population of $P$. lediniana is highly fragmented and is composed of six small clusters (thereafter sites). Only two of these sites had more than ten individuals and sampling for the genetic conservation study only targeted these two fragments (Fig. 2.2). In the other four sites, individuals were growing on inaccessible cliffs and DNA samples were unobtainable. The six sites extend along a $\sim 3 \mathrm{~km}$ stretch of a stream and are on private land. Currently around 20 families live in the area. On the basis of conversations with farmers from this area, during the rainy season this stream carries considerable amount of water and landslides are relatively common in the area. The palm does not have a specific name nor does it have any ethnobotanical use. Locally, this type of palm is referred to by the generic name of "Palmis Maron" and is shared with the royal palm (Roystonea borinquena O.F. Cook). The vegetation in this area is degraded lowland tropical broadleaved gallery forest growing on limestone cliffs [dominant plant species were: Acacia macracantha Willd. (Fabaceae), Bursera simaruba (L.) Sarg. (Burseraceae), Eugenia sp. (Myrtaceae), Haematoxylon campechianum L. (Fabaceae), Lantana camara L. (Verbenaceae), Panicum maximum Jacq. (Poaceae), Rondeletia sp. (Rubiaceae), and 
other widespread Caribbean low-elevation limestone species]. Despite not being reachable by road, most of the accessible hardwood trees and shrubs showed signs of being regularly cut (for charcoal production). The area was extensively disturbed, and local farmers reported that they burn the forest to plant subsistence staple crops such as sorghum, running beans, corn, cassava, and sweet potato. In July 2013 seeds were collected from the only reproductive individual for cultivation and there are currently 20 seedlings growing in the Botanic Garden of Cayes (Haiti).

\section{CONSERVATION GENETICS}

Only four of the seven loci were polymorphic (Table 2.1). The average number of alleles per locus was 2 , and Site 2 had three private alleles that were not found in the other site. Three multilocus genotypes where shared among different individuals. Four plants from Site 1 have identical multilocus genotypes, the same pattern was observed in two plants from Site 2. A single multilocus genotype was shared by two individuals from Site 1 and one from Site 2 . The global analyses showed that the population deviated significantly from HWE because of heterozygote deficit. The population had two loci that were not in HWE and it is highly inbred with a significantly positive Fis value of 0.508 .

The program Micro-Checker did not detect allelic dropout, but there was general excess of homozygotes for those loci-population combinations that were not in HWE (see above), suggesting that null alleles might be present for these loci. Although these loci may account for null alleles, the high number of homozygotes found in those loci could well be the outcome of genetic drift and inbreeding in this highly fragmented population with such a reduced number of individuals. 
The first and second axes of the PCO analysis accounted for approximately $67 \%$ of the genetic variation. The PCO scatter diagram showed most of the individuals from Site 2 with positive values along the second component. However, the diagram showed that individuals from the two collecting sites overlapped without a clear separation of two groups determined by site provenance (Fig. 2.3). The STRUCTURE analyses did not support the two collecting sites as two different clusters (Fig. 2.3).

\section{DISCUSSION}

\section{DISTRIBUTION PATTERNS AND CONSERVATION THREATS}

The results confirm that among the species of the genus, $P$. lediniana has the most restricted distribution and the lowest number of individuals in the wild. No other species of the genus is restricted to a single population. While both P. ekmanii and P. lediniana are Critically Endangered they have different conservation threats, distribution patterns, and protection status. Pseudophoenix ekmanii is currently protected in the National Park of Jaragua and a recent survey revealed that, although this species has a limited distribution range, some of its populations have between 330 and almost 2,500 individuals (Table 2.1; Namoff et al. 2011). With few exceptions the populations of $P$. ekmanii studied were composed of seedlings, juvenile, and adult individuals, even though, Namoff et al. (2011) found that in most of the locations individuals were tapped to produce "Mabí de Cacheo" (see above). Pseudophoenix lediniana is not harvested for making beverages but is restricted to a single and non-regenerating population with very few individuals. Its habitat is under more intense pressure because of massive forest clearance in a location without any official protection. 
Extensive field work conducted in the rest of the Dominican Republic with $P$. vinifera (Rodríguez-Peña 2013) shows the detrimental effect of a combination of massive sap extraction, removal of individuals for the horticultural trade, habitat destruction, and lack of official habitat protection. Rodríguez-Peña (2013) reported that populations of $P$. vinifera near human settlements with active agricultural activities tend to have distribution patterns similar to that of $P$. lediniana, i.e., highly fragmented populations with few individuals. These populations are found in highly degraded habitats and are under strong human utilization pressure. The palm trees are overexploited for their sap, and in many instances individual trees were removed to be planted in tourist and residential developments.

\section{CONSERVATION GENETIC AND MANAGEMENT IMPLICATIONS}

Palms are one of the most emblematic plant groups on islands (see above); however, few studies use DNA microsatellite data to address population/conservation genetic questions with them (i.e., Namoff et al. 2011; Shapcott et al. 2007, 2012a,b). The work of Shapcott et al. (2007) combined SSR and Amplified Fragment Length Polymorphism (AFLP) data. These studies focused on Critically Endangered or Endangered species (sensu IUCN (2013)) from the Dominican Republic [P. ekmanii (Namoff et al. 2011)], Madagascar [Beccariophoenix madagascariensis Jum. \& H. Perrier (Shapcott et al. 2007), and Lemurophoenix halleuxii J.Dransf. and Voanioala gerardii J.Dransf. (Shapcott et al. 2012b)], and Lord Howe Island [Lepidorrhachis mooreana (F. Muell.) O.F. Cook (Shapcott et al. 2012a)].

From a conservation genetic perspective, it has been suggested that a reduction of population size has two major effects on the genotype and allele frequencies of 
populations (DeSalle and Amato 2009). Alleles with higher frequency will be fixed through genetic drift (Allendorf and Luikart 2007) resulting in fewer polymorphic loci. In addition, proportion of homozygous individuals will increase through inbreeding, which results in a deficit of heterozygotes and reduced fitness (Höglund 2009). The few population genetic studies of threatened palms endemic to islands support these two conclusions. With the exception of Lemurophoenix halleuxii, populations of these threatened species were highly inbred with mean allelic fixation index values higher than 0.2. Significance tests (not reported for Lepidorrhachis mooreana) showed deviation of these populations from HWE with the mean observed heterozygosity lower than the mean expected heterozygosity in all comparisons. Among these studies, P. ekmanii and Voanioala gerardii (Shapcott et al. 2012b) were the only species that had all polymorphic loci. In the two other species the proportion of polymorphic loci ranged between $67 \%$ (for Lepidorrhachis mooreana (Shapcott et al. 2012a) and 70\% (for Lemurophoenix halleuxii (Shapcott et al. 2012b)).

The data for $P$. lediniana are in concordance with these conservation genetic expectations. Although the sampling included approximately one third of the individuals of the population of $P$. lediniana; robust conclusions pertinent to genetic diversity of $P$. lediniana cannot be inferred on the basis of only four polymorphic loci. However, these results provide some interesting insights pertinent to conservation genetics when they are compared with those from P. ekmanii (Namoff et al. 2010a). The latter species has multiple populations, with larger number of individuals, and the seven SSR loci were polymorphic in all the collecting sites. Therefore no alleles have been fixed in the populations of $P$. ekmanii (Namoff et al. 2010a). In contrast the Haitian species is 
restricted to a single population, with few individuals and three of the loci are monomorphic. Inbreeding coefficient values $(0.508$ in P. lediniana vs a maximum score of 0.3 in P. ekmanii) support higher levels of inbreeding in the former than in the latter. These results for $P$. lediniana are likely the consequence of a drastic decline in the population size of this species. The decline in population size resented in both genetic drift and inbreeding resulting in three loci with fixed alleles.

The wild population of the point endemic, $P$. lediniana, is at high risk of extinction, with a tiny population surviving in an unprotected and privately owned habitat, no regeneration has been observed and the habitat is subject to continued degradation by charcoal harvesting and subsistence agriculture. The current conservation status of $P$. lediniana reflects a situation that is being faced by other Caribbean Island threatened endemics in which lack of official habitat protection and management plans together with massive habitat clearance are major challenges for plant conservation (Maunder et al. 2008, 2011; Torres-Santana et al. 2010; Carey, in press).

Genetic erosion coupled with habitat degradation will be the critical factors to determine the viability of the species in the wild. The following steps to conserve this species are proposed. Priority should be given to the management of the wild population and to the protection of the surviving mature trees. A community conservation agreement with local farmers whereby incentives would be provided to protect the lone population could further the protection of this population. Further research is needed to understand the regeneration ecology of the species, for long-term conservation it is essential to establish a viable and regenerating wild population. Because of the unstable topographical conditions of the site where $P$. lediniana occurs, locating alternative areas 
on public land for species reintroduction is recommended. Equally important is an ex situ program as per the recommendations outlined by Maunder et al. (2001). While $P$. lediniana is currently being cultivated at the Botanic Garden of Cayes there is an urgent need to expand the founder representation in the cultivated stocks. Botanists from the Botanic Gaden of Cayes are making regular visits to the only wild population of $P$. lediniana in order to follow the phenology of this species, to outreach the local community, to determine seed predation patterns, and to collect germplasm to increase the current genetic stock for ex situ conservation. 


\section{REFERENCES}

Allendorf FW, Luikart G (2007) Conservation and the genetics of populations. Blackwell, Malden

Auld TD, Hutton I, Ooi MKJ, Denham AJ (2010) Disruption of recruitment in two endemic palms on Lord Howe Island by invasive rats. Biol Invas 12:3351-3361

Calonje M, Meerow AW, Knowles L, Knowles D, Griffith P, Nakamura K, FranciscoOrtega J (2013) Cycad biodiversity in the Bahama Archipelago and conservation genetics of the Critically Endangered Zamia lucayana (Zamiaceae). Oryx 47:190198

Cañellas-Boltà N, Rull V, Sáez A, Margalef O, Bao R, Pla-Rabes S, Blaauw M, ValeroGarcés B, Giralt S (2013) Vegetation changes and human settlement of Easter Island during the last millennia: a multiproxy study of the Lake Raraku sediments. Quatern Sci Rev 72:36-48

Carey E, Gape L, Manco BN, Hepburn D, Smith RL, Knowles L, Knowles D, Daniels M, Vincent MA, Freid E, Jestrow B, Griffith MP, Calonje M, Meerow AW, Stevenson DW, Francisco-Ortega J (in press) Plant conservation challenges in the Bahama archipelago. Bot Rev

Clase T, Peguero B (2006) Inventario preliminar de plantas exclusivas de Haití. In: Mejía Pimentel M, García R, Lagos-White S, Peguero B, Rodríguez S, Castillo D, Jiménez F, Veloz A, Zanoni T (eds) Libro de resúmenes. IX Congreso Latinoaméricano de Botánica. 18-25 de junio 2006. Jardín Botánico Nacional Dr. Rafael María Moscoso, Santo Domingo, p 140

Congreso Nacional de la República Dominicana (2004) Ley Sectorial de Áreas Protegidas, No. 202-04. http://www.wipo.int/wipolex/en/text.jsp?file_id=236193

DeSalle R, Amato G (2009) The expansion of conservation genetics. In: Amato G, Ryder $\mathrm{O}$, Rosenbaum H, DeSalle R (eds) Conservation genetics in the age of genomics. Columbia University Press, New York, pp 5-12

Dowe JL, Benzie J, Ballment E (1997) Ecology and genetics of Carpoxylon macrospermum H Wendl, Drude (Arecaceae), an endangered palm from Vanuatu. Biol Conservation 79:205-216

Earl DA (2011) Structure Harvester v0.6.7. http://users.soe.ucsc.edu/ dearl/software/structureHarvester/

Evanno G, Regnaut S, Goudet J (2005) Detecting the number of clusters of individuals using the software STRUCTURE: a simulation study. Molec Ecol 14:2611-2620 
Excoffier L, Laval G, Schneider S (2005) Arlequin ver. 3.0: an integrated software package for population genetics data analysis. Evol Bioinformatics Online 1:47$50 \mathrm{http} / / / \mathrm{cmpg} . u n i b e . c h /$ software/arlequin3/

Fleischmann K, Edwards PJ, Ramseier D, Kollmann J (2005) Stand structure, species diversity and regeneration of an endemic palm forest on the Seychelles. African J Ecol 43:291-301

Foxx RM (2012) Te Terre a fatige 'the Earth is tired': reversing deforestation in Haiti. Behavio. Interven 27:105-108

Francisco-Ortega J, Santiago-Valentín E, Acevedo-Rodríguez P, Lewis C, Pipoly III J, Meerow AW, Maunder M (2007) Seed plant genera endemic to the Caribbean Island biodiversity hotspot: a review and a molecular phylogenetic perspective. Bot Rev: 73:183-234

Francisco-Ortega J, Zona S (2013) Sweet sap from palms, a source of beverages, alcohol, vinegar, syrup, and sugar. Vieraea 41:91-113

Geiger JH, Meerow AW, Lewis C, Oviedo R, Francisco-Ortega J (2014) Genetic diversity and conservation of Ipomoea microdactyla (Convolvulaceae): an endemic vine from the Bahamas, Cuba, and southeastern Florida. Pl Spec Biol $29: 2-15$

Goudet J 1995. FSTAT version 1.2: a computer program to calculate F-Statistics. J Heredity 86:485-486

Guo SW, Thompson EA (1992) Performing the exact test of Hardy-Weinberg proportion for multiple allele. Biometrics 48:361-372

Henderson A, Aubry M, Timyan J, Balick M (1990) Conservation status of Haitian palms. Principes 34:134-142

Henderson AG, Galeano G, Bernal R (1995) Field guide to the palms of the Americas. Princeton University Press, New Jersey

Heywood VH (2001) The hazardous future of island flora. In: Bramwell D, CaujapéCastells J (eds) The Biology of island floras. Cambridge University Press, London, pp 488-510

Höglund J (2009) Evolutionary conservation genetics. Oxford University Press, Oxford

IUCN (2013) The IUCN red list of threatened species. Version 2013.1. http://www.iucnredlist.org/ 
Jakobsson M, Rosenberg NA (2007) CLUMPP: a cluster matching and permutation program for dealing with label switching and multimodality in analysis of population structure. Bioinformatics 14:1801-1806

Johnson D (1998) Palms: their conservation and sustained utilization. Status survey and conservation action plan. IUCN, Gland

Johnson D (1998) Copernicia ekmanii In: IUCN (ed) IUCN red list of threatened species. Version 2013.1 (IUCN 2013). http://www.iucnredlist.org

Jestrow B, Jiménez Rodríguez F, Francisco-Ortega J (2010) Generic delimitation in the Antillean Adelieae (Euphorbiaceae) with description of the Hispaniolan endemic genus Garciadelia. Taxon 59:1801-1814

Manohara TN, Linto EL, Renuka C (2010) Diversity and conservation of palms in Andaman, Nicobar archipelago. Biodivers \& Conservation 19:3655-3666

Maschinski J, Duquesnel J (2006) Successful reintroductions of the endangered longlived Sargent's cherry palm, Pseudophoenix sargentii, in the Florida Keys. Biol Conservation 134:122-129

Maunder M, Abdo M, Berazain R, Clubbe C, Jiménez F, Leiva A, Santiago-Valentín E, Francisco-Ortega J (2011) The plants of the Caribbean islands: a review of the biogeography, diversity and conservation of a storm-battered biodiversity hotspot. In: Bramwell D, Caujapé-Castells J (eds) The Biology of island floras. Cambridge University Press, London, pp 154-178

Maunder M, Leiva A, Santiago-Valentín E, Stevenson DW, Acevedo-Rodríguez P, Meerow AW, Mejía M, Clubbe C, Francisco-Ortega J (2008) Plant conservation in the Caribbean Island biodiversity hotspot. Bot Rev 74:197-207

Maunder M, Lyte B, Dransfield J, Baker W (2001) The conservation value of botanic garden palm collections. Biol Conservation 98:259-271

Maunder M, Page W, Mauremootoo J, Payendee R, Mungroo Y, Maljkovic A, Vericel C, Lyte B (2002) The decline and conservation management of the threatened endemic palms of the Mascarene Islands. Oryx 36:56-65

Meerow AW, Nakamura K (2007) Ten microsatellite loci from Zamia integrifolia (Zamiaceae). Molec Ecol Notes 7:824-826

Meerow AW, Francisco-Ortega J, Calonje M, Griffith MP, Ayala-Silva T, Stevenson DW, Nakamura K (2012) Zamia (Cycadales: Zamiaceae) on Puerto Rico: asymmetric genetic differentiation and the hypothesis of multiple introductions. Amer J Bot 99:1828-1839 
Meyer J-Y, Butaud J-F (2009) The impacts of rats on the endangered native flora of French Polynesia (Pacific Islands): drivers of plant extinction or coup de grâce species? Biol Invas 11:1569-1585

Morici C (2004) Palmeras e islas: la insularidad en una de las familias más diversas del reino vegetal. In: Fernández-Palacios JM, Morici, C (eds) Ecología insular / Island ecology. Asociación Española de Ecología Terrestre, Cabildo Insular de La Palma, pp 81-122

Morrison C, Rounds I, Watling D (2012) Conservation and management of the Endangered Fiji Sago Palm, Metroxylon vitiense, in Fiji. Environm Managem 49:929-941

Namoff S, Francisco-Ortega J, Zona S, Lewis CE (2010a) Microsatellite markers developed for the Caribbean palm Pseudophoenix sargentii - two PCR-based methods. Conservation Genet Resources 2:85-87

Namoff S, Husby C, Francisco-Ortega J, Noblick LR, Lewis CE, Griffith P (2010b) How well does a botanical garden collection of a rare palm capture the genetic variation in a wild population? Biol Conservation 143:1110-1117

Namoff S, Veloz A, Jiménez F, Rodríguez-Peña RA, Peguero B, Lewis C, Moynihan J, Abdo M, Maunder M, Meerow A, Von Wettberg E, Griffith P, Francisco-Ortega J (2011) Sweet drinks are made of this: conservation genetics of an endemic palm species from the Dominican Republic. J Heredity 102:1-10

Oleas N, Jestrow B, Calonje M, Peguero B, Jiménez F, Rodríguez-Peña R, Oviedo R, Santiago-Valentín E, Meerow AW, Abdo M, Maunder M, Griffith P, FranciscoOrtega J (2013) Molecular systematics of threatened seed plant species endemic in the Caribbean Islands. Bot Rev 79:528-541

Orloci L (1978) Multivariate analysis in vegetation research. Dr. W Junk B V, The Hague

Palmweb (2013) Palmweb: palms of the world online. http://www.palmweb.org

Paryski P, Woods CA, Sergile F (1989) Conservation strategies and the preservation of biological diversity in Haiti. In: Woods CA, Sergile FE (eds) Biogeography of the West Indies: patterns and perspectives. Biogeography of the West Indies: past, present, and future. Sandhill Crane Press, Gainesville, pp 855-878

Paskett CJ, Philoctete CE (1990) Soil conservation in Haiti. J Soil Water Conservation 45:457-459 
Peakall R, Smouse PE (2006) GENALEX 6: genetic analysis in Excel. Population genetic software for teaching and research. Molec Ecol Notes 6:288-295

Peakall R, Smouse PE (2012) GenAlEx 6.5: genetic analysis in Excel. Population genetic software for teaching and research - an update. Bioinformatics 28:2537-2539. http://bioinformatics.oxfordjournals.org/content/28/19/2537

Prebble M, Dowe JL (2008) The late Quaternary decline and extinction of palms on oceanic Pacific islands. Quatern Sci Rev 27:2546-2567

Pritchard JK, Stephens M, Donnelly P (2000) Inference of population structure using multilocus genotype data. Genetics 155:945-959

Ratsirarson J, Silander JA, Richard AF (1996) Conservation and management of a threatened Madagascar palm species, Neodypsis decaryi, Jumelle. Conservation Biol 10:40-52

Raymond M, Rousset F (1995) Genepop (version 1.2): population genetics software for exact tests and ecumenicism. J Heredity 86:248-249

Read RW (1988) Utilization of indigenous palms in the Caribbean (in relation to their abundance). Advances Econ Bot 6:137-143.

Rodríguez-Peña R (2013) Sampling Cherry Palms in the Dominican Republic. Trop Gard 68:55.

Rousset F, Raymond M (1995) Testing heterozygote excess and deficiency. Genetics 140:1413-1419

Rousset F (2008) Genepop'007: a complete reimplementation of the Genepop software for Windows and Linux. Molec Ecol Resources 8:103-106.

http://genepop.curtin.edu.au/

Rueger BF, von Wallmenich TN (1996) Human impact on the forests of Bermuda: the decline of endemic cedar and palmetto since 1609: recorded in the Holocene pollen record of Devonshire Marsh. J Paleolimnol 16:59-66

Santiago-Valentin E, Sustache J, Francisco-Ortega J, Figueroa-Hernández C, FuemeroCaban J, Griffith MP (2012) Pseudophoenix sargentii on Mona Island: conservation survey and a new discovery. Palms 56:78-90

Sergile FE, Woods CA (2001) Status of conservation in Haiti: a 10-year retrospective. In: Woods CA, Sergile FE (eds) Biogeography of the West Indies: patterns and perspectives. CRC Press, Boca Raton, pp 547-560 
Shapcott A, Rakotoarinivo M, Smith RJ, Lysaková G, Fay MF, Dransfield J (2007) Can we bring Madagascar's critically endangered palms back from the brink? Genetics, ecology and conservation of the critically endangered palm Beccariophoenix madagascariensis. Bot J Linn Soc 154:589-608

Shapcott A, Hutton I, Baker WJ, Auld TD (2012a) Conservation genetics and ecology of an endemic montane palm on Lord Howe Island and its potential for resilience. Conservation Genet 13:257-270

Shapcott A, Quinn J, Rakotoarivino M, Dransfield J (2012b) Contrasting patterns of genetic diversity between two endangered palms with overlapping distributions, Voanioala gerardii (Arecoideae) and Lemurophoenix halleuxii (Arecoideae), from North-east Madagascar. Conservation Genet 13:1393-1408

Slatkin M, Excoffier L (1996) Testing for linkage disequilibrium in genotypic data using the expectation maximization algorithm. Heredity 76:377-383

Smith ML, Hedges SB, Buck W, Hemphill A, Inchaustegui S, Ivie MA, Martina D, Maunder M, Francisco-Ortega J (2004) Caribbean Islands. In: Mittermeier RA, Gil RR, Hoffman M, Pilgrim J, Brooks T, Mittermeier CG, Lamoreux J, da Fonseca GAB (eds) Hotspots revisited: Earth's biologically richest and most threatened terrestrial ecoregions. CEMEX, Mexico DF, pp 112-118

Smouse PE, Peakall R (1999) Spatial autocorrelation analysis of individual multiallele and multilocus genetic structure. Heredity 82:561-573

Strahm W 1996. Botanical history of the Mascarene Islands. Curtis's Bot Mag 13:217228 .

Torres-Santana CW, Santiago-Valentín E, Leiva Sánchez AT, Peguero B, Clubbe C (2010) Conservation status of plants in the Caribbean Island Biodiversity Hotspot. In: Anonymous (ed) Proceedings of the Fourth Global Botanic Gardens Congress, June 2010. Dublin. http://www.bgci.org/files/Dublin2010/papers/Torres-SantanaChristian.pdf

Timyan JC, Reep SF (1994) Conservation status of Attalea crassispatha (Mart.) Burret, the rare and endemic oil palm of Haiti. Biol Conservation 68:11-18

Timyan JC, Hubbuch CE, Michal S (1997) Hunting for Mr. Straw Man. Principes 41:140-145.

Van Oosterhout C, Hutchinson WF, Wills DPM, Shipley P (2004) Micro- Checker: software for identifying and correcting genotyping errors in microsatellite data. Molec Ecol Notes 4:535-538. http://www.microchecker.hull.ac.uk/ 
Zanoni TA, Buck WR (1999) Navassa Island and its flora. 2. Checklist of the vascular plants. Brittonia 51:389-394

Zona S (2002) A revision of Pseudophoenix. Palms 46:19-38

Zona S, Verdecia R, Leiva Sánchez A, Lewis CE, Maunder M (2007) The conservation status of West Indian palms (Arecaceae). Oryx 41:300-305 
Table 2.1 Pseudophoenix lediniana and P. ekmanii population genetic statistics. Data for P. ekmanii from Namoff et al. (2011)

\begin{tabular}{|c|c|c|c|c|c|c|c|c|c|}
\hline $\begin{array}{l}\text { Species and } \\
\text { locality }^{\mathrm{a}}\end{array}$ & $\mathrm{P}$ & $\mathrm{n}_{\mathrm{p}}$ & A & $\mathrm{H}_{\mathrm{o}}$ & $\mathrm{H}_{\mathrm{e}}$ & $\mathrm{n}_{\mathrm{ds}}$ & $\mathrm{F}_{\text {is }}$ & $\mathrm{N}_{\mathrm{ig}}$ & LDL \\
\hline \multicolumn{10}{|l|}{ P. lediniana } \\
\hline Site $1(9 / 25)$ & 57 & 0 & 1.6 & 0.032 & 0.153 & 1 & $0.814^{* * *}$ & 2 & 0 \\
\hline Site $2(12 / 30)$ & 57 & 3 & 2 & 0.226 & 0.310 & 2 & $0.309 * * *$ & 2 & 17 \\
\hline Population (21/73) & 57 & na & 2 & 0.143 & 0.280 & 2 & $0.508 * * *$ & 4 & 17 \\
\hline \multicolumn{10}{|l|}{ P. ekmanii } \\
\hline Popul. 1 (25/329) & 100 & 1 & 2.8 & 0.288 & 0.451 & 5 & $0.300 * * *$ & 3 & 19 \\
\hline Popul. $2(31 / 550)$ & 100 & 3 & 4.9 & 0.442 & 0.666 & 5 & $0.211 * * *$ & 0 & 9 \\
\hline Popul. $3(22 / 496)$ & 100 & 7 & 5.4 & 0.528 & 0.591 & 4 & $0.255^{* * *}$ & 0 & 9 \\
\hline Popul. 4 (26/2475) & 100 & 3 & 4 & 0.459 & 0.580 & 5 & $0.214 * * *$ & 0 & 9 \\
\hline
\end{tabular}

Population genetic statistics are coded as follows: P, percentage of polymorphic loci; np, number of private alleles; A, average number of alleles per locus; Ho, observed heterozygosity; He, expected heterozygosity; nds, number of loci that deviate significantly from $\mathrm{HWE}(\mathrm{P}<0.05)$; Fis, inbreeding coefficient; Nig, number of identical genotype pairs; LDL, percentage of paired loci showing linkage disequilibrium. a Number of sampled individuals/total number of individuals are given inside the parenthesis. $* * *$ Values deviate significantly from $0(\mathrm{P}<0.05)$ 

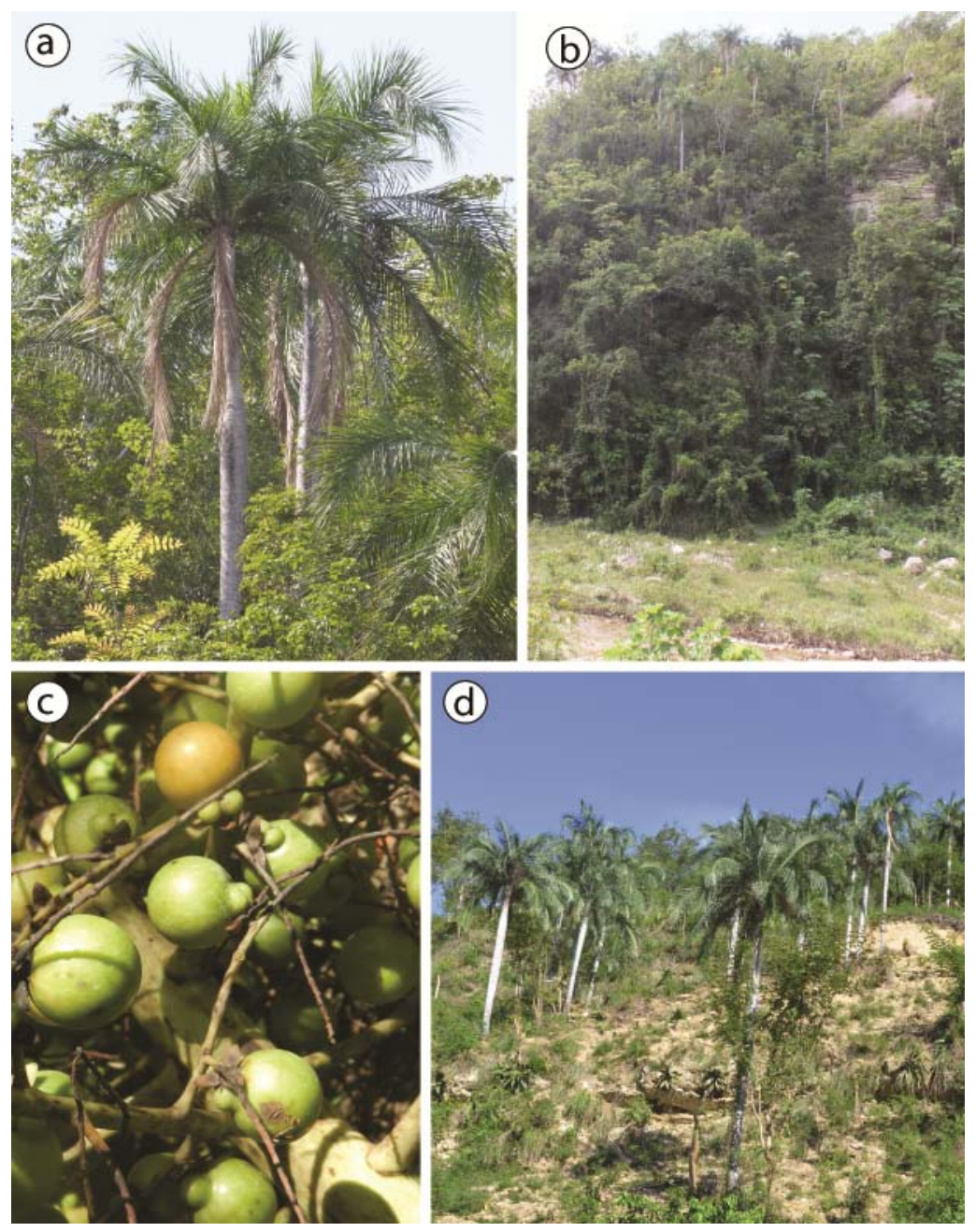

Fig. 2.1 Pseudophoenix lediniana: (a) Group of adult individuals (Site 2 for DNA sampling), (b) View of the habitat, notice the palms growing on the upper portion of the cliff and the stream on the bottom of the image (Site 2 for DNA sampling), (c) immature fruits, (d) view of the habitat showing the steep cliffs and lose substrate where the species grows (Site 1 for DNA sampling). 


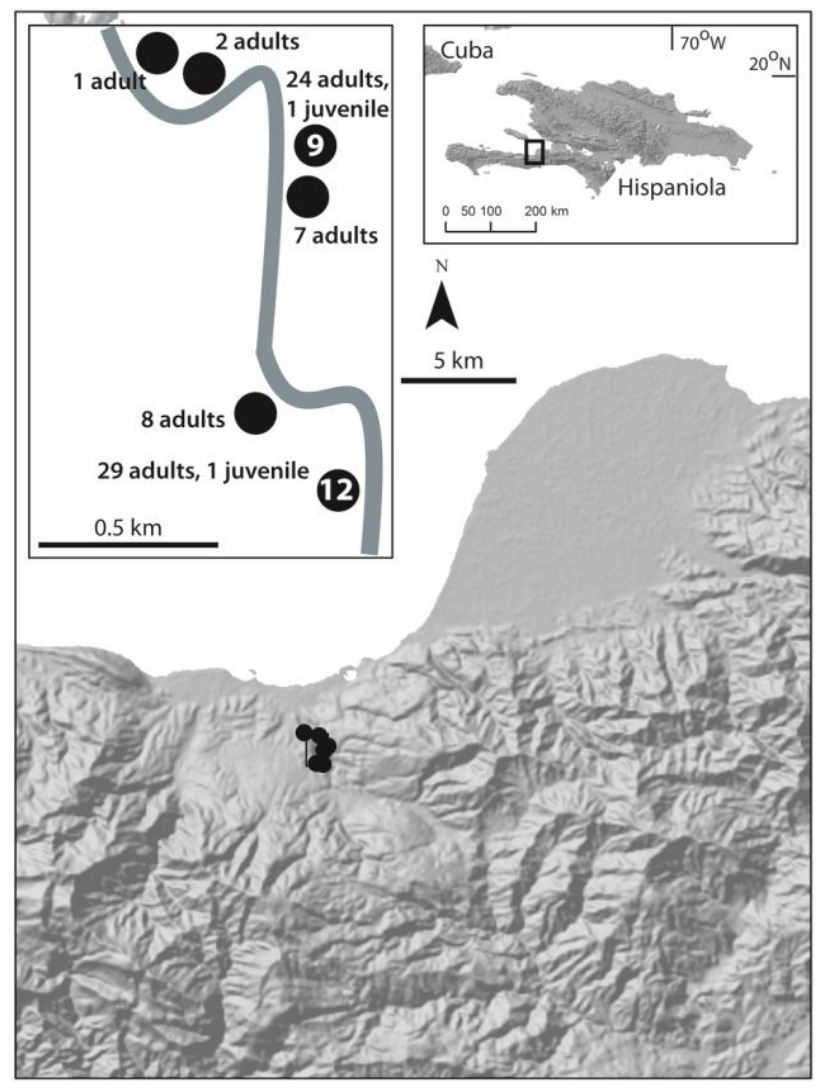

Fig. 2.2 Distribution of Pseudophoenix lediniana on Haiti, showing the spatial fragmented distribution of plants along the cliffs of a stream. Stream is shown in dark grey color. This is the only known population of this Haitian endemic palm. Each dot represents a site where plants were recorded. Numbers of adults and juveniles individuals found at in each site are indicated. The two sites were 9 (Site 1) and 12 (Site 2) plants were sampled for the genetic diversity study are also shown. 


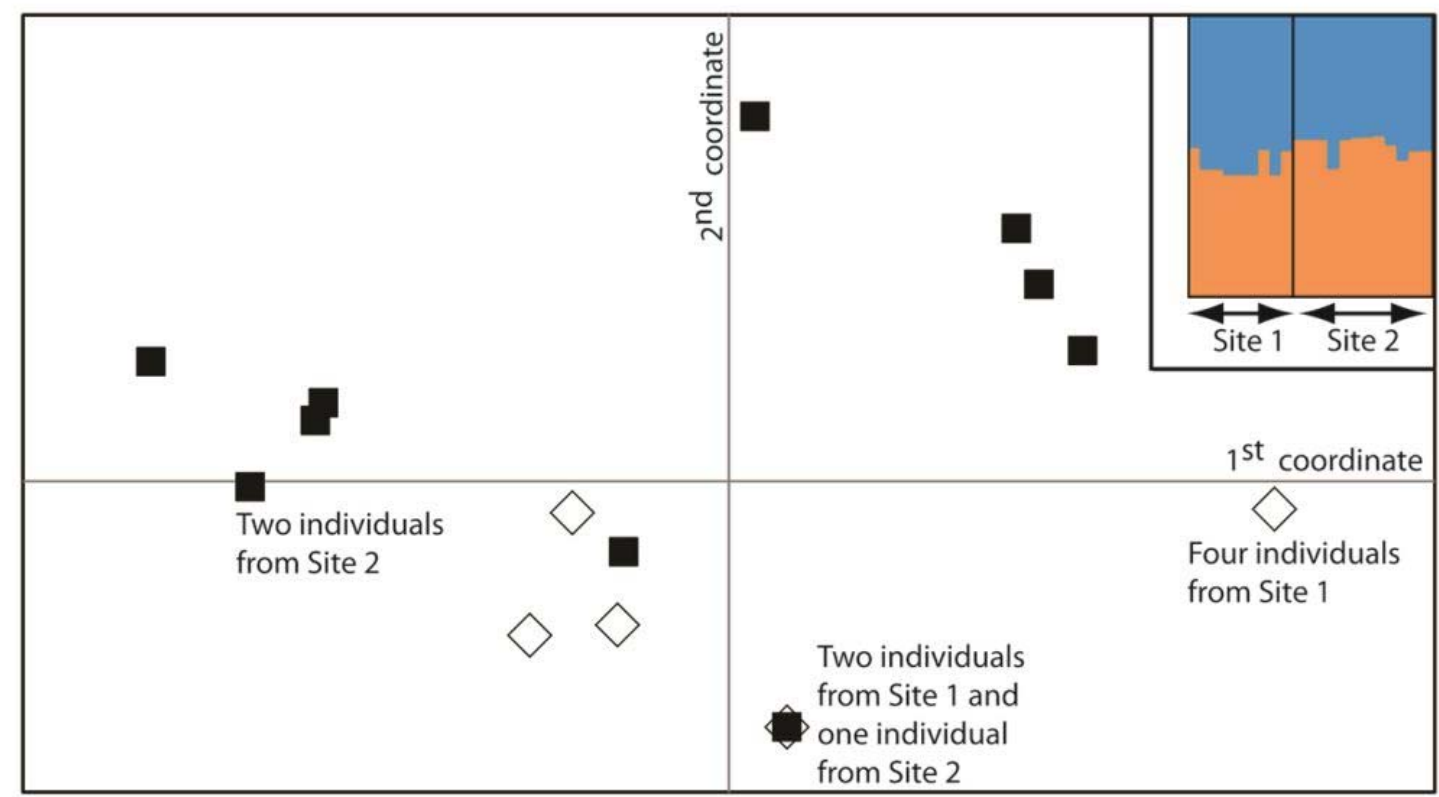

Fig. 2.3 Principal coordinate and STRUCTURE $(\mathrm{K}=2)$ analyses of DNA microsatellite data for the only known population of Pseudophoenix lediniana. The scatter diagram shows PCO values along the first two coordinates. Each point represents a single individual, except for the three indicated points that are for multiple individuals with the same multilocus genotype. Individuals for Site 2 are coded with filled symbols. Unfilled symbols refer to individuals from Site 1. Insert in upper right corner shows results yielded by STRUCTURE. Color and box sizes indicate the cluster type of each individual and the number of plants sampled per site. The vertical lines indicate the probability that each individual belongs to an inferred cluster. 


\section{CHAPTER III. GENETIC DIVERSITY AND DIFFERENTIATION OF PSEUDOPHOENIX (ARECACEAE) IN HISPANIOLA}

Hispaniola is the second largest island of the Caribbean Island Biodiversity Hotspot, and within this region it ranks second in plant endemism (Acevedo and Strong 2008). More than 4,000 species occur in Hispaniola, and over $41 \%$ of them are endemic (Acevedo and Strong 2012). In the Dominican Republic, more than $90 \%$ of the endemic plant species are threatened (Peguero and Jimenez 2011). The major factors affecting biodiversity conservation in Hispaniola are deforestation, unsustainable use of natural resources, urban development, and expansion of agricultural areas (Ottenwalder 1989; Paryski et al. 1989; Anonymous 1995; Bolay 1997).

Compared with other plant families (e,g, Asteraceae, Rubiaceae, Orchidaceae), the Arecaceae do not have many endemic species in the Caribbean Islands. However, palms from this biodiversity hotspot provide one of the best examples for biogeographical disjunctions within the tropics. The palm subfamily Ceroxyloideae has only eight genera, and they show a discontinuous distribution between the Caribbean (Pseudophoenix H.Wendl. ex Sarg.), South America (Ammandra O.F.Cook, Aphandra Barfod, Ceroxylon Bonpl. ex DC, Juania Drude, and Phytelephas Ruiz \& Pav.), Madagascar and the Comoros Islands (Ravenea C.D. Bouche), and Australia (Oraniopsis J. Dransf., A. K. Irvine \& N. W. Uhl) (Dransfield et al. 2008).

Compared with other palm subfamilies, the Ceroxyloideae appear to have a relatively recent origin, as this subfamily shared a common ancestor with its sister clade (the Arecoideae) approximately 52 MYA (Couvreur et al. 2011). Pseudophoenix is the only member of a lineage that is sister to the rest of the Ceroxyloideae. The lineage 
branched out approximately 40 MYA during the Eocene (Couvreur et al, 2011). Because of the complex geological history of the Caribbean Islands, with several episodes of transgression and subsidence, most of the West Indian biota is younger than the middle Eocene (Iturralde-Vinent and MacPhee 1999); therefore, the presence of Pseudophoenix in the Caribbean Islands fits well the palaeogeographical data available for the region.

Individuals of Pseudophoenix have pinnate leaves and a trunk shaped like a bottle; this morphological feature is more prominent in $P$. ekmanii and $P$. vinifera than in P. sargentii and P. lediniana. Inflorescences bear perfect flowers but produce a few staminate flowers at the end of the inflorescence (Zona 2002). Although field observations suggest that the genus is insect pollinated, Pseudophoenix flowers seem to be self-compatible, since isolated individuals growing in gardens produce viable seeds (Namoff et al. 2011).

Species of Pseudophoenix grow predominantly in dry forests over limestone soils (Zona 2002). In contrast, the rest of the species of the Ceroxyloideae occur mostly in tropical rain forests (Couvreu et al. 2011). The latest taxonomic treatment of the genus was published by Zona (2002). Hispaniola is the center of highest taxonomic diversity, as all four species of Pseudophoenix occur on this island (Figs. 3.1-3.2).

Pseudophoenix lediniana (Fig. 3.2) occurs in a single highly fragmented population close to the epicenter of the earthquake that struck Haiti in 2010. The habitat where it grows is highly disturbed. The species thrives on cliffs that are subject to frequent landslides during the rainy season. The site is usually burned to cultivate staple crops, and its woody species are regularly used to produce charcoal. The locality is not part of any protected area. 
Pseudophoenix ekmanii (Fig. 3.1) is restricted to southwestern Dominican Republic, specifically on Barahona Peninsula and Beata Island, where it is protected in the National Park of Jaragua. Despite its threatened conservation status, the species has large populations, and in a single site at "Sabana de Algodón," Namoff et al. (2011) reported over 2,400 individuals. The species was the subject of a recent population genetic study (Namoff et al. 2011), which showed strong evidence for genetic drift, inbreeding, and moderate gene flow among populations. These genetic population patterns were suggested to be the result of habitat fragmentation by human activities, unsustainable use of this species (see below), illegal extraction of palms for the horticulture trade, and destruction of adult individuals in order to gain access to nests of the Hispaniolan parrot, which is harvested for the exotic pet trade (Namoff et al. 2011). Pseudophoenix sargentii (Fig. 3.2) is the species of the genus with the widest distribution in the Caribbean. It is found in Florida (Biscayne National Park), Puerto Rico (Isla de Mona), Cuba, Navassa Island, Mexico (Yucatan), Belize, Lesser Antilles (Dominica), Haiti (Gonâve Island), and Dominican Republic (Saona Island and "Playa Palmilla", both in the "Parque Nacional del Este"), Turks and Caicos Islands, and the Bahamas. It usually occurs in coastal shores of dry forests although in Mexico and Belize it is also found inland. In some areas, populations of the species have been harvested for horticultural purposes. Good examples of this practice are the Florida populations in Long and Sands Keys, where the species is extinct (Lippincott 1992; Maschinski and Duquesnel 2006). Some populations in the Dominican Republic have been also been removed for tourism development and the horticultural trade. 
Pseudophoenix vinifera (Figs. 3.1-3.2) has a wide distribution in the western part of Hispaniola. It grows in dry lowland forests, but its distribution in Haiti is poorly known. The species has two core distribution areas in the Dominican Republic. The first one is in the southern sector of the country (Populations 5-8, see below, Fig. 3.1), located mostly on the lowlands between the Sierra de Neiba and the Sierra de Baoruco (along the "Hoya de Enriquillo") and between the Cordillera Central and the Caribbean Sea (Population 9, see below, Fig. 3.3). The second core area is on the northern part of the country and occupies the lowlands that separate the Cordillera Septentrional and the Cordillera Central predominantly along "Valle del Cibao" (Populations 10 and 11, see below, Fig. 3.3). During interglacial periods from the Miocene (Cibao) and Pleistocene (Enriquillo), these two valleys were largely below sea level (Mann et al. 1984; McNeill et al. 2012). The government of the Dominican Republic has established one reserve ("Monumento Natural Los Cacheos") near the border with Haiti to provide official protection to $P$. vinifera (Sectorial Law Number 202-04 for Protected Areas), specifically to prevent sap tapping and horticulture poaching, and to protect the palm's natural habitat (Congreso Nacional de la República Dominicana 2004). The species also occurs in "Monumento Nacional Las Caobas" and in the "Reserva Biológica Loma Charco Azul."

Zona (2002) indicated that plants of Pseudophoenix found in northwestern Dominican Republic (hereafter: Pseudophoenix sp. nova, Fig. 3.1) are morphologically distinct and might represent a new species. However, these observations were made on a single herbarium specimen. Zona (2002) decided not to provide any formal taxonomic description. The putative new taxon is highly threatened, and during field studies I could locate only a single population with approximately 34 individuals (Table 3.1, see below). 
Interestingly, this population occurs on serpentine soils; therefore, it is the only taxon in this genus to thrive in this unique soil environment characterized by a high content of nickel and magnesium (Lewis et al. 2006).

In the Dominican Republic, $P$. ekmanii and $P$. vinifera are used locally to prepare a sweet drink called "Mabí de Cacheo." Sap from juvenile trees is extracted to make this beverage; once they are tapped, the individual palms usually die (Francisco-Ortega and Zona 2013). The use of Pseudophoenix to prepare "Mabí de Cacheo" is one of the main reasons for the decline of these two species in the Dominican Republic (Namoff et al. 2011). Pseudophoenix lediniana does not have any known ethnobotanical use in Haiti; however, this species is highly threatened because of deforestation and habitat fragmentation (Henderson et al. 1990).

Two Pseudophoenix species are Critically Endangered (P. ekmanii and P. lediniana) sensu IUCN (2013). Both species have limited distribution areas. Pseudophoenix ekmanii is negatively affected by the unsustainable use of its sap and by illegal hunters who cut down palms in order to collect individuals of the endemic Hispaniolan parrot (Amazona ventralis) for the pet market. The crown of P. ekmanii is one of the nesting sites for this threatened and emblematic bird.

Microsatellites or Simple Sequence Repeats (SSRs) are molecular markers commonly used for population-level studies because they are codominant, biparentally inherited, and generally exhibit high levels of allelic diversity (Chase et al. 1996; Powell et al. 1996). These molecular markers can help to understand the biological features and the evolutionary history of a particular taxon (Fernandez-Silva et al. 2013). Recent examples of how SSRs have had a direct application for Caribbean endemic plants were 
reported for Ipomoea L. (Geiger et al. 2014), Pinus L. (Pinaceae) (Sanchez et al. 2014), Pseudophoenix (Namoff et al. 2011), Pterocarpus Jacq. (Fabaceae) (Muller et al. 2009), and Zamia L. (Meerow et al. 2012; Calonje et al. 2013). In these studies microsatellites have provided phytogeographical insights (Meerow et al. 2012; Geiger et al. 2014; Sanchez et al, 2014), have helped to define conservation management units for Critically Endangered species (Calonje et al. 2013), have revealed high levels of inbreeding in threatened species (Namoff et al. 2011), and have demonstrated limited gene flow among populations (Muller et al. 2009).

In this chapter I present the results, on the basis of SSR data, for a population genetic study of the species of Pseudophoenix that occur in Hispaniola. The primary goal was to use these molecular markers to determine if the taxonomic differentiation reported within this genus is also revealed by the molecular data. In addition SSRs were used to investigate the genetic structure and overall levels of genetic variation found in populations of this genus from Hispaniola.

MATERIALS AND METHODS

\section{STUDY SITES}

The study focused on localities from the Dominican Republic (14 populations); however, samples from the only known population of the Haitian endemic P. ledinina were also collected (Table 3.1, Fig. 3.3). The sampled sites represent the whole distribution area of the genus in the Dominican Republic. Three study sites were located in the north (populations 10 and 11 for $P$. vinifera, and population 12 for $P$. sp. nova), eight in the southwest (populations 2-4 for $P$. ekmanii and 5-10 for $P$. vinifera) and two in the southeast (populations $14-15$ for $P$. sargentii). For $P$. vinifera, I sampled, in 
protected areas (populations 5 from "Monumento Nacional Las Caobas, and 7 from Reserva Biológica Loma Charco Azul), unprotected localities where the species still has large numbers of individuals (populations 6 and 10), and unprotected sites that have been highly influenced by human activities (the remaining populations 8,9 and 11). I could not sample in "Monumento Nacional Los Cacheos", as the best stands of $P$. vinifera from this protected area were in remote areas that were difficult to access; however, the "Monumento Nacional Las Caobas" is adjacent to "Monumento Nacional Los Cacheos", and the present study included one population from this nature reserve. Samples of $P$. ekmanii were obtained from Fairchild Tropical Botanic Garden's DNA bank. These samples were previously used for a population genetic study focusing on this species (Namoff et al. 2011); however, the previous work was used seven SSR loci. For my study, I was able to obtain data for three additional loci (see below). Although the focus of my research was Hispaniola, samples of $P$. sargentii from Dominica, Turks and Caicos Islands, and Puerto Rico were also examined (Table 3.1, Fig. 3.3). These additional samples provided a wider biogeographical framework for the project. In total the population genetic study had samples from 18 populations (Table 3.1, Fig. 3.3). DNA AND DEMOGRAPHIC SAMPLING

For the molecular studies I collected plant material from at least 25 adult plants per population whenever it was possible. However, for some populations, I obtained fewer than 25 samples because population size was small (i.e., population 1 of $P$. lediniana and the two populations of $P$. sargentii from Mona Island) or some DNA isolations had a very low yield (i.e., population 14). The number of sampled plants ranged between 12 (Mona Island) and 46 (population 3 of $P$. ekmanii). 
Demographic inventories were performed to quantify the number of individuals within three plant classes: (1) seedlings (plants with fewer than 3 leaves); (2) juveniles (plants smaller than $1.5 \mathrm{~m}$ in height); and (3) adults (plants greater than $1.5 \mathrm{~m}$ in height). For the sampling performed in the Dominican Republic, the number of individuals that were tapped to prepare "Mabi de Cacheo" were quantified; tapped individuals have a man-made hole in the trunk right below the crown. Demographic studies for Mona Island included all the individuals found in these populations (Santiago Valentín et al. 2012). Demographic data for the only known population of $P$. lediniana were mostly obtained by observations performed with binoculars by two of the field team members. It was not possible to obtain actual censuses for all the area covered by this population, as most of its fragments were on inaccessible cliffs. Demographic data for the remaining populations were taken from initial censuses that covered approximately $10 \%$ of each of the visited sites. These data were subsequently extrapolated to the whole population area; therefore, they represent approximate estimates of the actual population.

DNA ISOLATIONS AND POLYMERASE CHAIN REACTION

Leaf samples were fast-dried in Drierite (W. A. Hammond Drierite Co. Ltd) and then used for DNA isolation with DNeasy Plant Mini Kit (Qiagen) following the manufacturer's protocol. Liquid nitrogen was used to disrupt the leaf tissues. Ten microsatellite loci (pse2.1, pse 3.11, pse3.33, pse3.34, pse3.6, pse5.2, pse5.4, pse5.5, pse5.6, and pse7.26), originally developed for P. sargentii by Namoff et al. (2010), were used as molecular markers for our study. For P. ekmanii, I was unable to recover PCR products for locus pse3.34. Therefore, subsequent data analyses that either combined all 18 populations or targeted the three populations of $P$. ekmanii were used only nine loci; 
the rest of the data analyses included data for the ten loci. The PCR conditions and amplification procedures followed the protocol described by Namoff et al. (2010). Samples were run on an ABI 3130XL Genetic Analyzer (Applied Biosystems) in the DNA core facility of Florida International University (FIU). Alleles were visualized and scored using Peak Scanner V1.0 (Applied Biosystems).

\section{DATA ANALYSES}

Tests for genotyping errors, null alleles, stuttering, and large allele dropout were conducted with Micro-Checker version 2.2.3 (Van Oosterhout 2004). The program GENALEX 6 v. 6.501 (Peakall and Smouse 2006, 2012) was used to quantify the number of private alleles and number of identical shared multilocus genotypes. The average number of alleles per locus, percent of polymorphic loci, observed heterozygosity, expected heterozygosity, and the percentage of paired loci showing linkage disequilibrium in each population were calculated with ARLEQUIN v. 3.5 (Excoffier et al. 2005). Tests for the number of loci that deviated from Hardy-Weinberg equilibrium (HWE) and the U test (Rousset and Raymond 1995) for heterozygote deficiency were run with GenePop v. 4.0 (Raymond and Rousset 1995; Rousset 2008) using 10,000 Markov chain Monte Carlo iterations (Guo and Thompson 1992) for each population. Inbreeding coefficients $\left(\mathrm{F}_{\text {is }}\right)$ were calculated for each population using FSTAT v. 1.2 (Goudet 1995). Analysis of molecular variance (AMOVA) among populations (using

\section{Euclidean squared distance matrix and with $\mathrm{P}$ values obtained after 1000} replicates) was obtained with ARLEQUIN. Values for the diversity measure $\mathrm{D}_{\text {est }}$ (Jost 2008) were obtained with SMOGD (Crawford 2010). The diversity index has been suggested to provide better estimates for population differentiation than the $\mathrm{G}_{\mathrm{st}}(\mathrm{Nei}$ 
1973) or $\mathrm{F}_{\text {st }}$ (Jost 2008; Heller and Siegismund 2009) indexes. To have estimations of levels of gene flow among populations, the pairwise number of migrants $\left(\mathrm{N}_{\mathrm{m}}\right)$ per generation between populations were computed with the program ARLEQUIN.

Pairwise genetic distances among populations were computed with POPULATIONS v. 1.2.30 (Langella 1999) using Chord distance (Cavalli-Sforza and Edwards 1967). The resulting inter-population pairwise genetic distances were then used to construct a Neighbor-joining (NJ) tree. Bootstrap analysis was carried out for the obtained network with POPULATIONS and was based on 10,000 permutations. The NJ tree was plotted using FigTree v. 1.4.0 (Rambaut 2012).

Principal coordinate analysis (PCO) among all the individuals from the 18 populations was computed with GENALEX. The analysis was used the algorithm developed by Orloci (1978), after conversion of the individual-by-individual genetic distance matrix, as defined by Smouse and Peakall (1999), to covariance matrix and data standardization.

The program STRUCTURE v.2.3.3 (Pritchard et al. 2000) was used to reveal the genetic structure among populations. $\mathrm{K}$ values from 1 to 19 were simulated across 20 replicate runs of $1,000,000$ iterations after a burn-in of 100,000 . The $\Delta \mathrm{k}$ method of Evanno et al. (2005), as found in STRUCTURE HARVESTER (Earl and vonHoldt 2012), was used to determine the 'true' value of K across samples. Once the likely level of $\mathrm{K}$ was estimated, a consensus Q-matrix from the 20 runs was constructed using CLUMPP (Jakobsson and Rosenberg 2007). Final results were visualized with DISTRUCT (Rosenberg 2004). Six different data sets were analyzed with the Bayesian clustering algorithm. The first one included data for all the individuals from the 18 
populations but only had data for nine loci (locus pse3.34 was excluded, see above). The second cluster analysis was also performed for only nine loci, and it included all individuals from the three populations of $P$. ekmanii. All ten loci were included in the four remaining data sets, and they were for: (1) the seven populations of $P$. vinifera; (2) the six populations of $P$. sargentii; (3) the six populations of $P$. sargentii together with the only population of $P$. sp. nova; and (4) the seven populations of $P$. vinifera plus the only known population of $P$. lediniana. Bayesian clustering analyses (3) and (4) were conducted because the NJ network and the PCO scatter diagram (see below) showed a close relationship between $P$. lediniana and $P$. vinifera and between $P$. sargentii and $P$. sp. nova.

To investigate whether a correlation exists between genetic and geographical distances, Mantel's tests of matrix correspondence (Mantel 1967) were conducted with GENALEX. Pairwise Nei's (1972) standard genetic distances among populations were used for these comparisons and they were computed with POPULATIONS. Three different sets of populations were analyzed, and they were for P. ekmanii, P. sargentii, and $P$. vinifera. Statistical significance for correlations was tested with 1000 random mutations and a 95\% confidence interval (Smouse et al. 1986; Smouse and Long 1992).

The program GENALEX was used to investigate spatial genetic structure (SGS). Tests were performed for all the populations except for those of $P$. sargentii from Mona Island and of $P$. lediniana. Geographical coordinates for individuals sampled on these sites were not available. The study was based on autocorrelation analysis using the multilocus genetic correlation coefficient $r$ (Smouse and Peakall 1999). 


\section{RESULTS}

\section{DEMOGRAPHIC STUDIES}

Demographic data for P. ekmanii were presented by Namoff el al. (2011) and therefore are not reported here. We analyzed 454 individual within 18 populations (Table 3.1). Pseudophoenix lediniana was the species with the fewest number of individuals (73 plants in its only known population). The majority of the individuals of this species were adults (71), and no seedlings were found (Table 3.1). Pseudophoenix sargentii had the widest distribution for the genus. For this species the population from Turks and Caicos had the highest number of individuals (325). Populations from three of the studied sites (those from Mona Island and Dominica) had fewer than 71 individuals and showed either no recruitment or very low numbers of juveniles and seedlings. We could not count seedlings for Population 14 (mainland Dominican Republic) because there were three other species of palm growing in the same area, and we were not able to discriminate among seedlings from these different palm species. The two largest populations of $P$. vinifera were located in protected areas (Population 7 at "Reserva Biológica Loma Charco Azul" with an estimate of 910 individuals and Population 5 at "Monumento Nacional Las Caobas" with 610 individuals). Interestingly, we could not locate any seedlings in Population 6, despite this being the population of $P$. vinifera with the third largest number of individuals (460). The only known site of $P$. sp. nova (Population 12) had the third lowest number of individuals (34) among all the populations of Pseudophoenix included in this study. Contrary to original expectations, in none of the populations individuals that appeared to have been tapped to produce Mabí de Cacheo were located 


\section{GENETIC VARIABILITY}

The final data matrix included genetic information for 454 individuals and had 1.7\% of missing data. Population 4 (P. ekmanii from Isla Beata) and Population $14(P$. sargentii from the Dominican Republic) had the highest proportion of missing data $(9.6 \%$ and 4.7\%, respectively). Loci pse5.2 (3.7\%) and pse7.26 (4.8\%) had the highest percentage of missing data. Allele sizes ranged from 129 (locus pse3.34) to $479 \mathrm{bp}$ (locus pse5.2). The total number of alleles across all populations and loci was 243 with a mean population value of 13.5 alleles.

The nine loci studied for P. ekmanii were polymorphic for all localities, except for the Isla Beata population, which exhibited only seven polymorphic loci. All loci amplified for P. lediniana (Population 1), but just four loci were polymorphic for this Haitian species. All loci were polymorphic for all the populations of $P$. sargentii from the Dominican Republic (Populations 14 and 15). However, just eight loci were polymorphic for the two P. sargentii sites from Mona Island (Populations 16 and 17) and Dominica (Population 18). Most loci were polymorphic for all populations of $P$. vinifera (Populations 5-11) with the exception of Population 9, which had nine polymorphic loci. (Table 3.2). The only population of $P$. sp. nova did not have any monomorphic loci. Population 13 (P. sargentii site from Turks and Caicos) had the largest number of alleles per locus $(\mathrm{A}=8.4)$, while the only population of $P$. lediniana had the lowest value $(\mathrm{A}=$ 1.7, Table 3.2). We found 59 private alleles with an average value of $n_{p}=3.3$ per population. Population 13 had the largest number of private alleles $\left(n_{p}=9\right)$ and Population 18 (P. sargentii site from Dominica) was the only locality that did not have private alleles (Table 3.2). 
The U-tests showed that all populations departed significantly from HWE and displayed heterozygote deficiency (mean $\mathrm{H}_{0}$ value across all populations of 0.28 vs mean $\mathrm{H}_{\mathrm{e}}$ value across all populations of 0.52 , Table 3.2). Four of the populations that did not have monomorphic loci had more than seven loci that deviated significantly from HWI (Population 3 of $P$. ekmanii, Population 8 of $P$. vinifera, the only population of $P$. sp. nova, and Population 8 of $P$. sargentii) (Table 3.2). The six populations with monomorphic loci showed that at least $75 \%$ of their polymorphic loci deviated significantly from HWE. The average inbreeding coefficient value among all populations was 0.43 . The two highest values for this coefficient were found in Population 16 ( $P$. sargentii from Mona Island, $\left.\mathrm{F}_{\mathrm{is}}=0.67\right)$ and Population $9(P$. vinifera from Bahía de Ocoa, $\mathrm{F}_{\text {is }}=0.63$, Table 3.2). The two lowest $\mathrm{F}_{\text {is }}$ values were exhibited by $P$. sargentii (Population 13 from Turks and Caicos $\left(\mathrm{F}_{\text {is }}=0.34\right)$ and Population 15 from Saona Island $\left.\left(\mathrm{F}_{\text {is }}=0.37\right)\right)$.

Identical multilocus genotypes were detected only in Populations 1 (P. lediniana, $\left.\mathrm{N}_{\mathrm{ig}}=6\right), 4\left(P\right.$. ekmanii, $\left.\mathrm{N}_{\mathrm{ig}}=1\right)$, and $9\left(\right.$ P. sargentii, $\left.\mathrm{N}_{\mathrm{ig}}=1\right)$. All populations had at least four pairs of loci in linkage disequilibrium (Table 3.2). Populations 4 (P. ekmanii), 9 ( $P$. vinifera), 12 ( $P$. sp. nova), and 14 ( $P$. sargentii) had the largest percentage of paired loci in linkage disequilibrium ( $\mathrm{LDL}=33 \%$ ). The three sampling sites with the lowest proportion of paired loci in linkage disequilibrium were found in P. lediniana (Population 1), P. vinifera (Population 10), and P. sargentii (Population 17) (LDL $=4 \%$ in these three populations).

No evidence of large allele dropout was found in any locus; however, the MICROCHECKER output indicated that there was general homozygote excess 
suggesting the presence of null alleles. Although these loci may have null alleles, the high proportion of homozygotes detected in this study could also be the consequence of stochastic genetic processes and high levels of autogamy. In addition, no locus had excess of homozygotes in all populations. This provided additional support to interpret the MICOCHECKER results as evidence for true homozygote excess instead of presence of null alleles.

There were no clear relationships between population size and levels of genetic diversity. For example the two smallest sampled populations (those from Mona Island) had only 2.1 average alleles per locus and both displayed a low $\mathrm{H}_{\mathrm{o}}$ value of 0.15 (Population 16) and 0.2 (Population 17). However, the results also showed notable exceptions to these initial predictions. For instance the population of $P$. sargentii from Turks and Caicos (325 individuals) displayed the highest $\mathrm{H}_{\mathrm{o}}$ value (0.44) and the highest number of alleles per locus (8.4) among all the sampled sites; however, this population did not have the highest number of individuals. Another exception was provided by Population 2 (P. ekmanii), which had the second largest number of individuals $(2,475)$ but exhibited a low average number of alleles per locus (3.7) and a low $\mathrm{H}_{\mathrm{o}}$ value (0.22). Likewise, the very small population of $P$. sp. nova (34 individuals) had the second highest number of alleles per locus (6.3) and a relatively high $\mathrm{H}_{\mathrm{o}}$ value of 0.36 . Similar patterns were detected in two small populations of $P$. vinifera, Population 8 with 53 individuals and Population 11 with 76 individuals, which displayed high $\mathrm{H}_{\mathrm{o}}$ values of 0.31 and 0.34 , respectively. Indeed, none of the populations with more than 400 individuals had $\mathrm{H}_{\mathrm{o}}$ scores higher than 0.3. 


\section{GENETIC DIFFERENTIATION AMONG POPULATIONS}

The mean value for the diversity measure of Jost (2008) across all populations was 0.75 , suggesting high differentiation among populations (Table 3.3). However, there was a trend for $\mathrm{D}_{\text {est }}$ values to be much larger among populations from different species than among conspecific populations. The highest $\mathrm{D}_{\text {est }}$ value was 0.98 and it was found between three populations of $P$. ekmanii and $P$. vinifera (Populations 2 and 5, Populations 2 and 7, and Populations 4 and 7). The lowest differentiation was found between Populations 14 and 15 of $P$. sargentii from the Dominican Republic $\left(\mathrm{D}_{\mathrm{est}}=0.05\right)$.

Average $\mathrm{N}_{\mathrm{m}}$ values were 0.99 for all the samples. In most pairwise comparisons the number of migrants per generation was much higher between conspecific populations than among populations from different species (Table 3.3). The highest $\mathrm{N}_{\mathrm{m}}$ values were obtained among conspecific populations located in close geographical proximity. The two highest of these values were between Populations 14 and 15 of $P$. sargentii from the Dominican Republic $\left(\mathrm{N}_{\mathrm{m}}=8.55\right)$ and Populations 2 and 3 of $P$. ekmanii $\left(\mathrm{N}_{\mathrm{m}}=2.94\right)$. Interestingly, the third highest value for this migration index was between the population of $P$. sp. nova and the population of $P$. sargentii from Turks and Caicos $\left(\mathrm{N}_{\mathrm{m}}=2.69\right)$.

The AMOVA analyses indicated that $24 \%$ of the genetic variation is found among species. These analyses also showed that $22 \%$ of the variation was found among populations within species and $54 \%$ of the variation within populations.

The result of the Mantel tests revealed that genetic and geographic distance among populations were correlated both for $P$. sargentii $(\mathrm{r}=0.82, P=0.02)$ and for $P$. vinifera $(\mathrm{r}=0.69, P=0.003)$. 


\section{POPULATION STRUCTURE}

The first and second coordinates of the PCO explained only $23.51 \%$ of the genetic variation. Pseudophoenix vinifera and P. lediniana samples tended to have high positive values along the first PCO axis, and they grouped together (Fig. 3.4). In contrast, those individuals belonging to the three populations of $P$. ekmanii exhibited low scores along this first axis and formed a distinct cluster. Samples of $P$. sargentii and $P$. sp. nova displayed low values along the second coordinate and clustered together.

The NJ network recovered four groups that were concordant with the current taxonomy (Fig. 3.5). Each of these groups corresponds to one of the four species currently recognized with the genus. Interestingly, the only known site of $P$. sp. nova was part of the group that had the populations of $P$. sargentii and it was closely related to the population from Turks and Caicos.

The $\Delta K$ method of Evanno et al. (2005) suggested a "true value" of $K=11$ clusters across all 18 populations of Pseudophoenix (Fig. 3.6). The results obtained using the Bayesian clustering analyses were consistent with species delimitation; therefore, populations shared clusters within species but not among species. Populations of $P$. lediniana, $P$. ekmanii, and $P$. sp. nova grouped into one different cluster each. The six populations of $P$. sargentii were assigned to three different clusters. Individuals of this species from Dominica mostly exhibited the first of these three clusters. Turks and Caicos samples were largely assigned to the second cluster. Finally those individuals of $P$. sargentii from Mona Island, Saona, and the main island of Hispaniola mostly were allocated to the third cluster. The seven populations of $P$. vinifera were distributed into five clusters. Samples from Populations 5, 7, and 8 primarily belonged to one different 
cluster each, and little admixture was detected among them. These three clusters were very rarely found in the four remaining populations of $P$. vinifera. Samples from the two localities of this species from northern Dominican Republic (Populations 10 and 11) were predominantly assigned to another cluster that was not present in the other populations. Finally individuals from the two sites from southern Dominican Republic (Populations 6 and 9) mostly belonged to a cluster that was very rarely detected in the remaining populations.

When the Bayesian clustering analysis was run individually for each species, similar results were found only for $P$. sargentii (optimal $K=3$, Fig. 3.6b) and $P$. vinifera (optimal $K=5$, Fig. 3.6d). Association patterns between the samples of these two species and their recovered clusters were very similar to those yielded by the 18 population analysis (compare Fig. 3.6a and Fig 3.6b for P. sargentii and compare Fig. 3.6a and Fig. 3.6d for $P$. vinifera).

The Evanno method identified an optimal $K=3$ from the analysis of the data matrix that combined samples of $P$. sargentii and $P$. sp. nova (Fig. 3.6c). This analysis clearly supported a close genetic connection between the only known site of $P$. sp. nova and that of $P$. sargentii from Turks and Caicos. All members from these two populations were mostly assigned to a single cluster. Cluster membership for the remaining five populations of $P$. sargentii followed the pattern detected in the separate analysis that only targeted this species (Fig. 3.6b).

Results from the Bayesian clustering analysis of the P. ekmanii samples (optimal $\mathrm{K}=4$ ) (Fig. 3.6e) were different from those found after the analysis of the 18 populations (Fig. 3.6a). The global analysis suggested that all the individuals of this species belonged 
to a single cluster. However, the separate analysis showed that samples from Populations 2 and 4 of P. ekmanii were mostly assigned to one different cluster each, although a few individuals of these sites exhibited admixture with other clusters (Fig. 3.6e). The two remaining clusters were primarily confined to Population 3 , but they showed admixture mostly involving these two clusters.

The analysis performed for the single population of P. lediniana and the populations of P. vinifera suggested an optimal $K$ value of 3 (data not shown). This separate analysis assigned all the individuals of $P$. lediniana to a single cluster that was not present in any of the samples of $P$. vinifera. The remaining two clusters were restricted to the populations of $P$. vinifera.

\section{DISCUSSION}

\section{GENETIC DIVERSITY AND DIFFERENTIATION}

There is a general assumption that smaller populations tend to harbor lower genetic diversity than larger ones (Oostermeijer et al. 2003). The results of this study did not concur with this prediction as there was not a clear association between population size and genetic diversity estimates.

These unexpected results might be the consequence of relatively recent habitat fragmentation or population size decline coupled with the life-cycle features of Pseudophoenix. Although no data concerning the environmental history of the targeted populations was gathered for this study, it is well known that since the 15 th century, the Caribbean Islands, and particularly the Dominican Republic, have experienced extensive habitat fragmentation and forest clearance associated with rapid human developments (Sambrook et al 1999; Alscher 2011). Currently, the Caribbean Islands rank third in 
human population density among the Biodiversity Hotspots (Cincotta et al. 2000), and just between 2000 and 2012, the Dominican Republic experienced an average annual human population growth of $1.45 \%$, which is one of the highest rates for the Western Hemisphere (Anonymous 2014). Individuals of Pseudophoenix have long life cycles with an estimated reproductive age of 57 years (Duran 1995). It has been suggested that these kinds of long-lived organisms will show the negative impact of genetic drift on genetic diversity only after several hundreds of years because they have long generation times and overlapping cohorts (Glémin et al. 2006; Duminil et al. 2007, 2009).

Overall, the analysis of population genetic structure showed high genetic differentiation, high genetic variation within populations, and high inbreeding coefficients. For each of the species, the Isolation-by-Distance analysis showed that as geographical distance increases, genetic similarity decreases. This tendency was stronger in $P$. sargentii probably because of the larger geographical distances among populations in this species, which spreads across several islands. The $\mathrm{D}_{\text {est }}$ values supported higher differentiation among species than within populations of the same species. Likewise, the number of migrants $\left(\mathrm{N}_{\mathrm{m}}\right)$ was low among species but high among populations of the same species. These results suggested that gene-flow is more relevant within conspecific populations than among populations belonging to different species. A notable exception to this pattern was found for Populations 5 and 6 ( $P$. vinifera). These two sites are only $14 \mathrm{~km}$ apart but display high $\mathrm{D}_{\text {est }}$ values (0.31) and low $\mathrm{Nm}$ (1.2) scores, suggesting limited genetic differentiation between them.

In four pairwise comparisons, populations from different islands showed little genetic differentiation. The two most relevant examples were found between the main 
island of Hispaniola and the small islands of Beata (Population 2 vs Population 3 of $P$. ekmanii) and Saona (Population 14 vs Population 15 of $P$. sargentii). Pairwise $\mathrm{D}_{\text {est }}$ values for these two population comparisons were the lowest detected in the study. In addition, their $\mathrm{N}_{\mathrm{m}}$ scores were among the highest in the analysis. The islands of Beata and Saona are 29 and $13 \mathrm{~km}$ away from the main island of Hispaniola, respectively. It is likely that both of them were connected to the current Hispaniola during the last glacial period $(\sim 12,000$ years ago) because of the shallow waters $(<15 \mathrm{~m})$ of the straits that separate them (UASD 2002a, 2002b). Gene-flow cannot be ruled as a mechanism to account for the little differentiation shown by these populations; however, it is plausible that the detected $\mathrm{N}_{\mathrm{m}}$ and $\mathrm{D}_{\text {est }}$ values are the result of recent vicariance events that followed the rise of sea-level that separated these small islands from the current island of Hispaniola during the Holocene. Little inter-island genetic differentiation was also detected among (1) populations of $P$. sargentii from Hispaniola and those from Mona Island and (2) the population of $P$. sargentii from Turks and Caicos and that of $P$. sp. nova from northern Dominican Republic. Deep waters separate these two islands from Hispaniola, and thus they were not connected to the latter during the last glacial period. Therefore, over-water dispersal is the only biogeographical avenue to explain the high $\mathrm{N}_{\mathrm{m}}$ and low $\mathrm{D}_{\text {est }}$ values exhibited in these two inter-island population comparisons.

The inbreeding coefficients across all the populations were high and significant. Contrary to the initial expectations, $\mathrm{F}_{\text {is }}$ values were highly positive even in those sites that had a high number of individuals. These results suggested that expected fixation of alleles across populations via (1) low genetic migration because of habitat fragmentation (see above) and (2) stochastic events associated with genetic drift of small populations are not 
the only evolutionary mechanisms behind the genetic structure of the species. It is well known that small isolated populations are more likely to have high levels of inbreeding as a consequence of limited gene flow and a higher frequency of mating among relatives (Leimu et al. 2006; Herron and Freeman 2013); however, in this study both small and large populations show evidence of reduced genetic diversity and inbreeding.

An alternative explanation is that population genetic structure is influenced not only by genetic drift and migration but also by breeding systems and their associated patterns of reproductive biology (Young et al. 1996). Generic drift is a strong evolutionary force in small populations but almost insignificant in large populations (Ouborg et al. 2006), and its effect is greatly diminished in species with long generation times

According to Duminil et al. (2007), mating system is one of the major factors that influence the population genetic structure of any plant species. Breeding systems will have a strong effect on population genetic structure regardless of population size and age. It is expected that outcrossing species will show low genetic differentiation among populations, high within-population genetic diversity, and low levels of inbreeding, particularly in large populations (Hamrick and Godt, 1996). In contrast, it is expected that a rapid increase of homozygote frequencies across generations without changes in allele frequencies will occur for those species that have self-pollination as their primary reproductive strategy (Herron and Freeman 2013).

No studies have been conducted pertinent to the reproductive biology and breeding systems of Pseudophoenix (Barfod et al. 2011). However, isolated individuals of the genus have been found to produce seeds, suggesting that they are self-compatible 
(Zona pers. comm.). The high $\mathrm{F}_{\text {is }}$ values found across all of the populations sampled for this study suggest that these casual observations from botanic gardens might confirm that self-pollination is an important feature of the reproductive biology of this genus and could explain the levels of inbreeding shown by the results.

Two other population genetic studies based on SSRs that mostly focused on plants from the Caribbean Islands have also reported low levels of genetic diversity and high $\mathrm{F}_{\text {is }}$ values (Muller et al. 2009; Geiger et al. 2014). One of these studies concerned populations of a self-incompatible species (i.e., Geiger et al. 2014). In this case, the authors attributed the reduced levels of genetic diversity and significantly high inbreeding coefficients to genetic drift and mating among relatives. This example involved species with reduced population size within a highly fragmented habitat. However, the second study (Muller et al. 2009) suggested that the high $\mathrm{F}_{\text {is }}$ values found in populations of Pterocarpus officinalis Jacq. (Fabaceae) could be attributed both to stochastic events related to genetic drift and to breeding systems that promote self-pollination.

\section{TAXONOMIC IMPLICATIONS}

Results from the Bayesian and Neighbor Joining cluster analyses were consistent with the current taxonomy of the genus as published by Zona (2002). Additionally, no indication of admixture between populations belonging to different species was found. The NJ tree showed that the vast majority of the populations grouped according to their current taxonomic assignment, with the exception of Population 12 ( $P$. sp. nova), which formed a cluster with P. sargentii from Turks and Caicos (Fig. 3.5). This cluster was part of another group that included all of the populations of $P$. sargentii (Fig 3.5). Zona (2002) was unable to assign plants of Pseudophoenix from northern Dominican Republic 
(i.e., $P$. sp. nova) to any particular taxon, indicating that further studies were needed to clarify the taxonomic placement of this morph. Zona's (2002) morphological studies showed that plants belonging to $P$. sp. nova have a combination of unique traits not found in any other species of the genus. They include three-sided calyxes and ovoid fruits (as in P. vinifera) and divaricating rachillae (as in P. sargentii). However, his conclusion was based on the study of a single herbarium specimen. A full taxonomic and morphological study of Pseudophoenix is beyond the scope of this thesis. However, systematic studies are in progress to clarify the placement of this enigmatic morph and determine its specific identity (Rodríguez-Peña and Zona in prep.).

The results of this thesis showed that microsatellites markers have taxonomic value and that they can be useful for species delimitation. SSRs are not believed to be good molecular markers for phylogenetic reconstructions, as there are uncertainties concerning their mutation model (Jarne and Lagoda 1996). In addition, the utility of microsatellite allele frequencies to obtain phylogenies has been questioned (Scribner and Pearce 2000).

Microsatellite markers have been widely used in palm population genetic studies (e.g., Kaneko et al. 2011; Nazareno et al. 2011; Abreu et al. 2012; Menezes et al. 2012; Ramos et al. 2012; Cibrián-Jaramillo et al. 2013), but these works have mostly focused on research pertinent to population genetic diversity, genetic conservation, and genetic structure. Two particular studies have used these markers to address taxonomic questions. The first one concerned Phoenix atlantica A.Chev., and it supported this Cape Verde Island endemic as a distinct species, clearly differentiated from $P$. dactylifera $\mathrm{L}$. (Henderson et al. 2006). The second one was conducted by Bacon et al. (2012), who 
analyzed microsatellites and DNA nucleotide sequence data to investigate species boundaries within Pritchardia in Hawaii. However, the authors failed to reach robust conclusions because of rampant interspecific hybridization.

\section{CONSERVATION IMPLICATIONS}

Not all the species and sites included in this study are located inside protected areas. For instance, all of the populations of P. ekmanii are protected in the National Park of Jaragua, whereas the only known population of P. lediniana is found on private land and is not the subject of any in situ conservation initiative (see further details pertinent to the conservation status of these two species in Chapter 2). Concerning $P$. vinifera, the populations from the northern area of the Dominican Republic are not protected, but two of the populations from southern Dominican Republic are located inside the nature reserves of "Monumento Natural Las Caobas" or of "Reserva Biológica Loma Charco Azul." The P. sargentii populations from Mona Island and the Dominican Republic are also found on protected areas. However, no in situ conservation actions have been developed for $P$. sp. nova and $P$. sargentii from the Dominican Republic and Turks and Caicos, respectively. Field observations found that all of the populations that are located outside nature reserves (except for Population 6 of $P$. vinifera on Jimaní) have a reduced number of individuals and are in areas with human disturbance in a highly fragmented habitat. The two populations of Mona Island are the only ones that are found inside a protected area that have severely reduced population sizes of 14 and 24 individuals.

Among the species of the genus, $P$. lediniana and $P$. sp. nova should have the highest priority for conservation because they are restricted to one population each and have a reduced number of individuals. The extremely reduced levels of genetic diversity 
found in P. lediniana (see Chapter 2) stresses the importance to have in situ conservation action plans for this species. Contrary to initial expectations, the only population of $P$. sp. nova exhibited relatively high $\mathrm{H}_{\mathrm{o}}$ values, had $100 \%$ polymorphic loci, and had the second highest average number of alleles per locus among all the populations included in the study.

The lack of clear relationships between levels of genetic diversity and population size (see above) was also found when comparisons were made between protected and unprotected sites. Contrary to what was anticipated, protected areas do not harbor most of the genetic diversity of the genus. Possible reasons for these results are the recent creation of these protected areas. Established in 1975, the "Parque Nacional del Este" is the oldest of the protected areas of the Dominican Republic where Pseudophonenix occurs (Hernández et al. 1990). The nature reserve of Mona Island was created in 1919 (Sastre de Jesús and Santiago-Valentín, 1996); however, this island has serious problems with feral goats and pigs, both of which are extremely detrimental to the native flora (Santiago-Valentín et al. 2012). In addition, even the protected areas often have poor conservation enforcement and are under severe anthropogenic pressure by local communities who exploit these forests (Powell and Inchaustegui 2009).

Overall the results support Isolation-by-Distance for the study sites (see above); however, in many instances populations of $P$. vinifera that were geographically distant were more similar than those that were geographically close. These unexpected patterns for population similarities might well reflect past gene-flow routes and common population ancestry that have been disrupted by habitat fragmentation. It is likely that such a disruption has been enhanced by small population sizes and the breeding system of 
Pseudophoenix, which appears to favor self-pollination. Therefore it is suggested that future conservation efforts should aim to maintain population connectivity and increase population size, particularly targeting those populations where low genetic diversity was detected.

Species delimitation is very important for conservation management (Frankham et al. 2002). Without a clear idea of what needs to be protected, it is almost impossible to prepare sound conservation action plans. The results of this thesis help delineate Pseudophoenix species boundaries and identify taxa for which conservation actions are required immediately.

\section{CONCLUSION}

Population genetic diversity in Pseudophoenix species was poorly related to the size of most populations, but these results are in concordance with recent habitat fragmentation coupled with the life history strategies of Pseudophoenix. Generally, genetic differentiation and within-population genetic variability were high. More study is needed in order to establish the influence of reproductive biology in shaping the genetic structure of Pseudophoenix populations. Microsatellite data support the current taxonomy of Pseudophoenix. Field observations suggest that this genus is very sensitive to human disturbance, and it is likely that habitat fragmentation together with negative human activities will have stronger conservation genetic consequences in the near future. In order to counteract these impacts, conservation action initiatives should be implemented as soon as possible. 


\section{REFERENCES}

Abreu AG, Priolli RHG, Azevedo-Filho JA, Nucci SM, Zucchi MI, Coelho RM, and Colombo CA (2012) The genetic structure and mating system of Acrocomia aculeata (Arecaceae). Genet Molec Biol 35:119-21

Acevedo-Rodríguez P, Strong MT (2008) Floristic richness and affinities in the West Indies. Bot Rev 74(1):5-36

Acevedo-Rodríguez P \& Strong MT eds (2012) Catalogue of seed plants of the West Indies. Smithsonian Contrib Bot 98:1-1192

Anonymous (1995) Una estrategia para la conservación de la biodiversidad de la República Dominicana. 1994-2003. Centro Editorial, Santo Domingo

Aparicio A, Hampe A, Fernández-Carrillo L, Albaladejo RG (2012) Fragmentation and comparative genetic structure of four mediterranean woody species: complex interactions between life history traits and the landscape context. Divers Distrib $18: 226-235$

Bacon CD, McKenna MJ, Simmons MP, Wagner WL (2012) Evaluating multiple criteria for species delimitation: an empirical example using Hawaiian palms (Arecaceae: Pritchardia). BMC Evol Biol 12:23

Barfod AS, Hagen M, \& Borchsenius F (2011) Twenty-five years of progress in understanding pollination mechanisms in palms (Arecaceae). Ann Bot 108:15031516

Bolay E (1997) The Dominican Republic. A country between rain forest and desert. Contributions to the ecology of a Caribbean island. Margraf Verlag, Weikersheim, Germany

Calonje M, Meerow AW, Knowles L, Knowles D, Griffith P, Nakamura K, FranciscoOrtega J (2013) Cycad biodiversity in the Bahama Archipelago and conservation genetics of the Critically Endangered Zamia lucayana (Zamiaceae). Oryx 47:190198

Cavalli-Sforza LL, Edwards AWF (1967) Phylogenetic analysis. Models and estimation procedures. Amer J Hum Genet 19:233-257

Cibrián-Jaramillo A, Hird A, Oleas N, Ma H, Meerow AW, Francisco-Ortega, Griffith MP (2013) What is the conservation value of a plant in a botanic garden? Using indicators to improve management of ex situ collections. Bot Rev 79:559-577 
Cincotta RP, Wisnewski J, Engelman R (2000) Human population in the biodiversity hotspots. Nature 204:990-992

Congreso Nacional de la República Dominicana (2004) Ley sectorial de áreas protegidas, No. 202-04. http://www.wipo.int/wipolex/en/text.jsp?file_id=236193

Chase M, Kesseli R, Bawa K (1996) Microsatellite markers for population and conservation gene tics of tropical trees. Amer J Bot 83:51- 57

Couvreur TLP, Forest F, Baker, WJ (2011) Origin and global diversification patterns of tropical rain forests: inferences from a complete genus-level phylogeny of palms. BMC Biol 9:44

Crawford NG (2010) SMOGD: software for the measurement of genetic diversity. Molec Ecol Resour 10:556-557

Dransfield J, Uhl NW, Asmussen CB, Baker JW, Harley MM, Lewis CE (2008) Genera palmarum: The evolution and classification of palms. Kew Publishing, Kew, Great Britain

Duminil J, Fineschi S, Arndt H, Jornado P, Salvini D, Vendramin GG, Petit RJ (2007) Can population genetic structure be predicted from life-history traits? The Amer Natur 169:662-672

Duminil J, Hardy OJ, Petit RJ (2009) Plant traits correlated with generation time directly affect inbreeding depression and mating system and indirectly genetic structure. BMC Evol Biol 9:177

Durán, R (1995) Pseudophoenix sargentii: an endangered palm species. Principes 39:219-224

Earl DA, Vonholdt BM (2012) STRUCTURE HARVESTER: a website and program for visualizing STRUCTURE output and implementing the Evanno method. Conservation Genet Resources 4:359-361

Evanno G, Regnaut S, Goudet J. 2005. Detecting the number of cluster of individuals using the software STRUCTURE: a simulation study. Molec Ecol 14:2611-2620

Excoffier L, Laval G, Schneider S (2005) Arlequin ver. 3.0: an integrated software package for population genetics data analysis. Evol Bioinformatics Online 1:4750. http://cmpg.unibe.ch/software/arlequin3/

Fernandez-Silva I, Whitney J, Wainwright B, Andrews KR, Ylitalo-Ward H, Bowen BW, Toonen RJ, Goetze E, Karl SA (2013) Microsatellites for next-generation ecologists: a post-sequencing bioinformatics pipeline. PLOS One 8:e55990 
Francisco-Ortega J, Zona S (2013) Sweet sap from palms, a source of beverages, alcohol, vinegar, syrup, and sugar. Vieraea 41:91-113

Frankham R (1997) Do island populations have less genetic variation than mainland populations? Heredity 78:311-327

Geiger JH, Meerow AW, Lewis C, Oviedo R, Francisco-Ortega J (2014) Genetic diversity and conservation of Ipomoea microdactyla (Convolvulaceae): an endemic vine from the Bahamas, Cuba, and southeastern Florida. Pl Spec Biol 29:2-15

Glémin S, Bazin E, Charlesworth D (2006) Impact of mating systems on patterns of sequence polymorphism in flowering plants. Proc Biol Sci 273:3011-3019

Goudet J (1995) FSTAT version 1.2: a computer program to calculate F-Statistics. J Heredity 86:485-486

Hamrick J L, Godt MJW (1996). Effects of life history traits on genetic diversity in plant species. Philos Trans, Ser B 351:1291-1298

Heller R, Siegismund HR (2009) Relationships between three measures of genetic differentiation $\mathrm{G}_{\mathrm{st}}, \mathrm{De}_{\mathrm{st}}$ and $\mathrm{G}$ 'st: how wrong have we been? Molec Ecol 18:2080-2083

Henderson A, Aubry M, Timyan J, Balick M (1990) Conservation status of Haitian palms. Principes 34:134-142

Henderson, S. a., Billotte, N., \& Pintaud, J.-C. (2006). Genetic isolation of Cape Verde Island Phoenix atlantica (Arecaceae) revealed by microsatellite markers. Conservation Genet 7: 213-223

Hernandez C, Bautista E, Schubert A (1990) Situación actual de la conservación de la biodiversidad In: Departamento de Vida Silvestre, Secretaría de Estado de Agricultura (ed) La diversidad biológica en la República Dominicana. Departamento de Vida Silvestre, Secretaría de Estado de Agricultura, Deutscher Entwicklungsdienst, World Wildlife Fund, Santo Domingo, pp 151-202

Herron JC, Freeman S (2013) Evolutionary analysis. 5th ed. Benjamin Cummings

Iturralde-Vinent MA, MacPhee RDE (1999) Paleogeography of the Ca-ribbean region: implications for Cenozoic biogeography. Bull Amer Mus Nat Hist 238:1-95

IUCN (2013) The IUCN red list of threatened species. Version 2013.1. http://www.iucnredlist.org/ 
Jakobsson M, Rosenberg NA (2007) CLUMPP: a cluster matching and permutation program for dealing with label switching and multimodality in analysis of population structure. Bioinformatics 23:1801-1806

Jarne P, Lagoda PJL (1996) Microsatellites, from molecules to populations and back. Trends Ecol Evol 10:424-429

Jost L (2008) $\mathrm{G}_{\mathrm{st}}$ and its relatives do not measure differentiation. Molec Ecol 17:40154026

Kaneko S, Kondo T, Isagi Y (2011) Development of microsatellite markers for the northern Australian endemic fan palm Livistona rigida (Arecaceae), with crossamplification in the five related species. Conservation Genet Resour 3:697-699

Langella O (1999) Populations, version 1.2.30. A population genetic software. CNRS, UPR9034. http://bioinformatics.org/;tryphon/populations/

Leimu R, Mutikainen P, Koricheva J, Fischer M (2006). How general are positive relationships between plant size, fitness and genetic variation? population. J Ecol 94:942-952

Lewis JF, Draper G, Proenza JA, Espaillat, Jimenez J (2006) Ophiolite-related ultramafic rocks (serpentinites) in the Caribbean region: a review of their occurrence composition, origin, emplacement and Ni-laterite soils formation. Geologica Acta $4: 237-263$

Lippincot C (1992) Restoring Sargent's Cherry Palm on the Florida Keys. Fairchild Trop Gard Bull 47(1):12-21

Mann P, Taylor FW, Burke K, Kulstad R (1984) Subaerially exposed Holocene coral reef, Enriquillo Valley, Dominican Republic. Geol Soc Amer Bull 95:1084-1092

Mantel N (1967) The detection of disease clustering and a generalized regression approach. Cancer Res 27:209-220

McNeill DF, Klaus JS, Budd AF, Lutz BP, Ishman SE (2012) Late Neogene chronology and sequence stratigraphy of mixed carbonate-siliciclastic deposits of the Cibao Basin, Dominican Republic. Geol Soc Amer Bull 124:35-58

Maschinski J, Duquesnel J (2006) Successful reintroductions of the endangered longlived Sargent's cherry palm, Pseudophoenix sargentii, in the Florida Keys. Biol Conservation 134:122-129 
Meerow AW, Francisco-Ortega J, Calonje M, Griffith MP, Ayala-Silva T, Stevenson DW, Nakamura K (2012) Zamia (Cycadales: Zamiaceae) on Puerto Rico: asymmetric genetic differentiation and the hypothesis of multiple introductions. Amer J Bot 99:1828-1839

Menezes E V, Souto WFS, Ciampi a Y, et al. (2012) Development and characterization of DNA microsatellite primers for buriti (Mauritia flexuosa L.f.). Genet Molec Res 11:4058-4062

Muller F, Voccia M, Bâ A, Bouvet JM (2009) Genetic diversity and gene flow in a Caribbean tree Pterocarpus officinalis Jacq.: a study based on chloroplast and nuclear microsatellites. Genetica 135:185-198

Namoff S, Francisco-Ortega J, Zona S, Lewis CE (2010) Microsatellite markers developed for the Caribbean palm Pseudophoenix sargentii - two PCR-based methods. Conservation Genet Resources 2:85-87

Namoff S, Veloz A, Jiménez F, Rodríguez-Peña RA, Peguero B, Lewis C, Moynihan J, Abdo M, Maunder M, Meerow A, Von Wettberg E, Griffith P, Francisco-Ortega J (2011) Sweet drinks are made of this: conservation genetics of an endemic palm species from the Dominican Republic. J Heredity 102:1-10

Nei M (1972). Genetic distance between populations. Amer Natur 106:283-292

Nei M (1973) Analysis of gene diversity in subdivided populations. Proc Natl Acad Sci USA 70:3321-3323

Nazareno AG, Zucchi MI, dos Reis MS (2011) Microsatellite markers for Butia eriospatha (Arecaceae), a vulnerable palm species from the Atlantic rainforest of Brazil. Amer J Bot 98:e198-200

Orloci L (1978) Multivariate analysis in vegetation research. Dr. W Junk B V, The Hague

Oostermeijer JGB, Luijten SH, den Nijs JCM (2003) Integrating demographic and genetic approaches in plant conservation. Biol Conservation 113:389-398

Ouborg NJ, Vergeer P, Mix C (2006) The rough edges of the conservation genetics paradigm for plants. J Ecol 94:1233-1248

Paryski P, Woods CA, Sergile F (1989) Conservation strategies and the preservation of biological diversity in Haiti. In: Woods CA (ed) Biogeography of the West Indies. Past, present, and future. Florida Museum of Natural History, Gainesville, pp $855-878$ 
Peakall R, Smouse PE (2006) GENALEX 6: genetic analysis in Excel. Population genetic software for teaching and research. Molec Ecol Notes 6:288-295

Peakall R, Smouse PE (2012) GenAlEx 6.5: genetic analysis in Excel. Population genetic software for teaching and research - an update. Bioinformatics 28:2537-2539. http://bioinformatics.oxfordjournals.org/content/28/19/2537

Peguero B, Jiménez F (2011) Inventario y estado de conservación de las plantas vasculares exclusivas de la Republica Dominicana. Moscosoa 17:29-57

Powell R, Inchaustegui SJ (2009) Conservation of the herpetofauna of the Dominican Republic. Applied Herpetol 6:103-122

Powell W, Machray GC, Provan JA (1996) Polymorphism revealed by simple sequence repeats. Trends P1 Sci 1:215-222

Pritchard JK, Stephens M, Donnelly P (2000) Inference of population structure using multilocus genotype data. Genetics 155:945-959

Rambaut A (2012) FigTree v1.3.1. Program available online. http://tree.bio.ed.ac.uk/software/figtree

Ramos SLF, de Macêdo JLV, Lopes MTG, et al. (2012) Microsatellite loci for tucumã of Amazonas (Astrocaryum aculeatum) and amplification in other Arecaceae. Amer J Bot 99:e508-10

Rosenberg NA (2004) DISTRUCT: a program for the graphical display of population structure. Molec Ecol Notes 4:137-138

Rousset F (2008) Genepop'007: a complete reimplementation of the Genepop software for Windows and Linux. Molec Ecol Resources 8:103-106. http://genepop.curtin.edu.au/

Rousset F, Raymond M (1995) Testing heterozygote excess and deficiency. Genetics 140:1413-1419

Sanchez M, Ingrouille MJ, Cowan RS, Hamilton MA, Fay MF (2014) Spatial structure and genetic diversity of natural populations of the Caribbean pine, Pinus caribaea var. bahamensis (Pinaceae), in the Bahaman archipelago. Bot J Linn Soc 174:359-383

Santiago-Valentín E, Sustache-Sustache J.; Francisco-Ortega J, Cielo Figuerola C, Fumero-Cabán J, Griffith P (2012) Pseudophoenix sargentii on Mona Island: Conservation survey and a new discovery. Palms 56:78-90 
Sarthou C, Samadi S, Boisselier-Dubayle M-C (2001) Genetic structure of the saxicole Pitcairnia geyskesii (Bromeliaceae) on inselbergs in French Guiana. Amer J Bot $88: 861-868$

Sastre De Jesús I, Santiago-Valentín E (1996) Botanical explorations of Puerto Rico by N. L. Britton and E. G. Britton: their significance in plant conservation, horticulture and education. Brittonia 48:322-336

Scribner KT, Pearce JM (2000) Microsatellites: evolutionary and methodological background and empirical applications at individual, population, and phylogenetic levels. In: Baker A (ed) Molecular methods in ecology. Blackwell Science, Oxford, pp 235-273

Slatkin M, Excoffier L (1996) Testing for linkage disequilibrium in genotypic data using the expectation maximization algorithm. Heredity 76:377-383

Smouse PE, Long JC (1992) Matrix correlation analysis in anthropology and genetics. Amer J Phys Anthropol 35:187-213

Smouse PE, Long JC, Sokal RR (1986) Multiple regression and correlation extensions of the Mantel test of matrix correspondence. Syst Biol 35:627-632

Smouse PE, Peakall R (1999) Spatial autocorrelation analysis of individual multiallele and multilocus genetic structure. Heredity 82:561-573

UASD (2002a) Universidad Autónoma de Santo Domingo: Mapa topografico general: [Dominican Republic] [cartographic material]. Santo Domingo: Instituto Geográfico Universitario NE 19-5

UASD (2002b). Universidad Autónoma de Santo Domingo: Mapa topografico general: [Dominican Republic] [cartographic material]. Santo Domingo: Instituto Geográfico Universitario NE 19-7

Van Oosterhout C, Hutchinson WF, Wills DPM, Shipley P (2004) Micro- Checker: software for identifying and correcting genotyping errors in microsatellite data. Molec Ecol Notes 4:535-538. http://www.microchecker.hull.ac.uk/

Young A, Boyle T, Brown T (1996) The population genetic consequences of habitat fragmentation for plants. Trends Ecol Evol 11:413-418

Zona S (2002) A revision of Pseudophoenix. Palms 46:19-37 


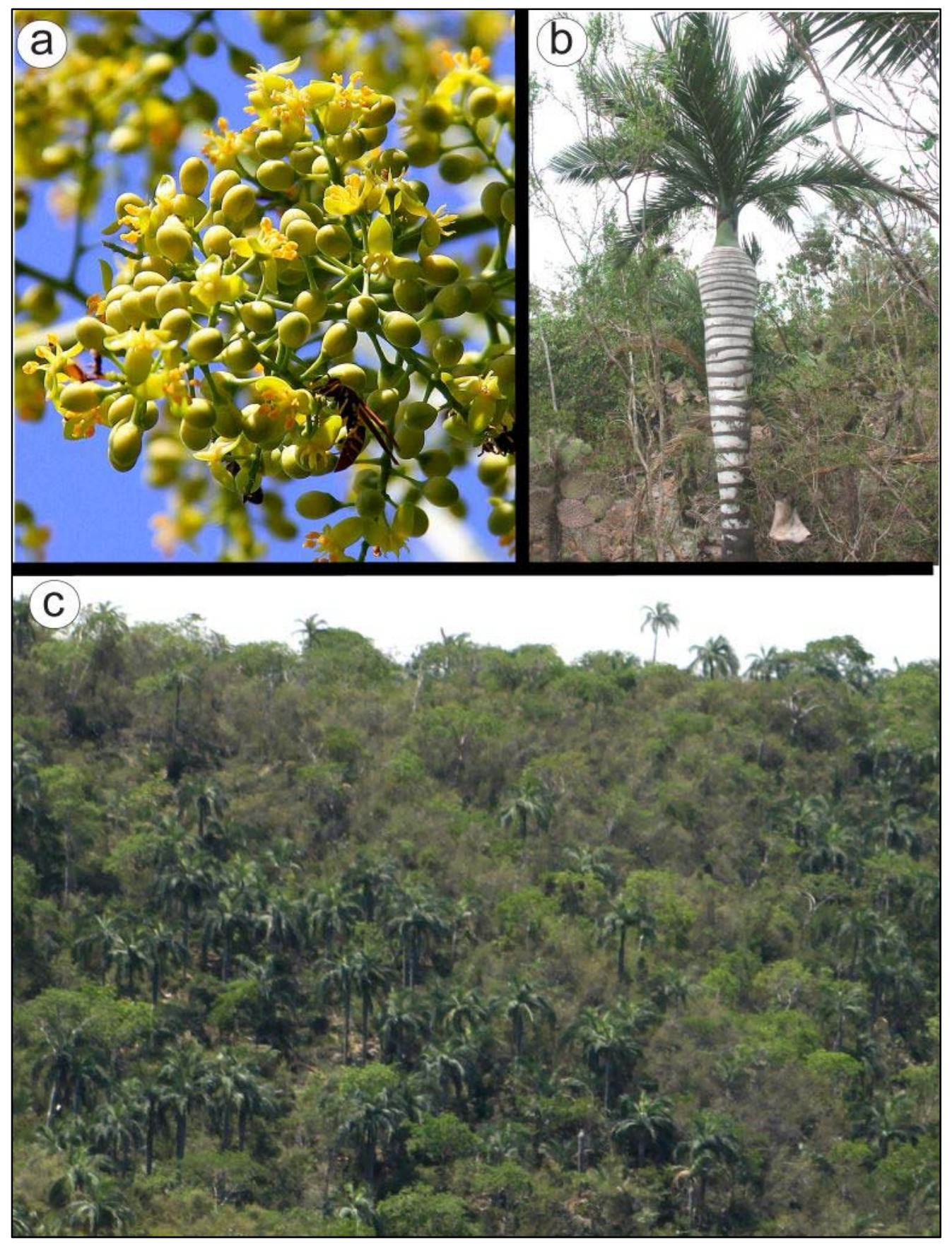

Fig 3.1. Pseudophoenix plants in Dominican Republic. a Inflorescence of $P$. sp. nova; $\mathrm{b}$ Adult individual of $P$. ekmanii; c Dense stand of $P$. vinifera in Jimaní. Images by Rosa Rodríguez. 


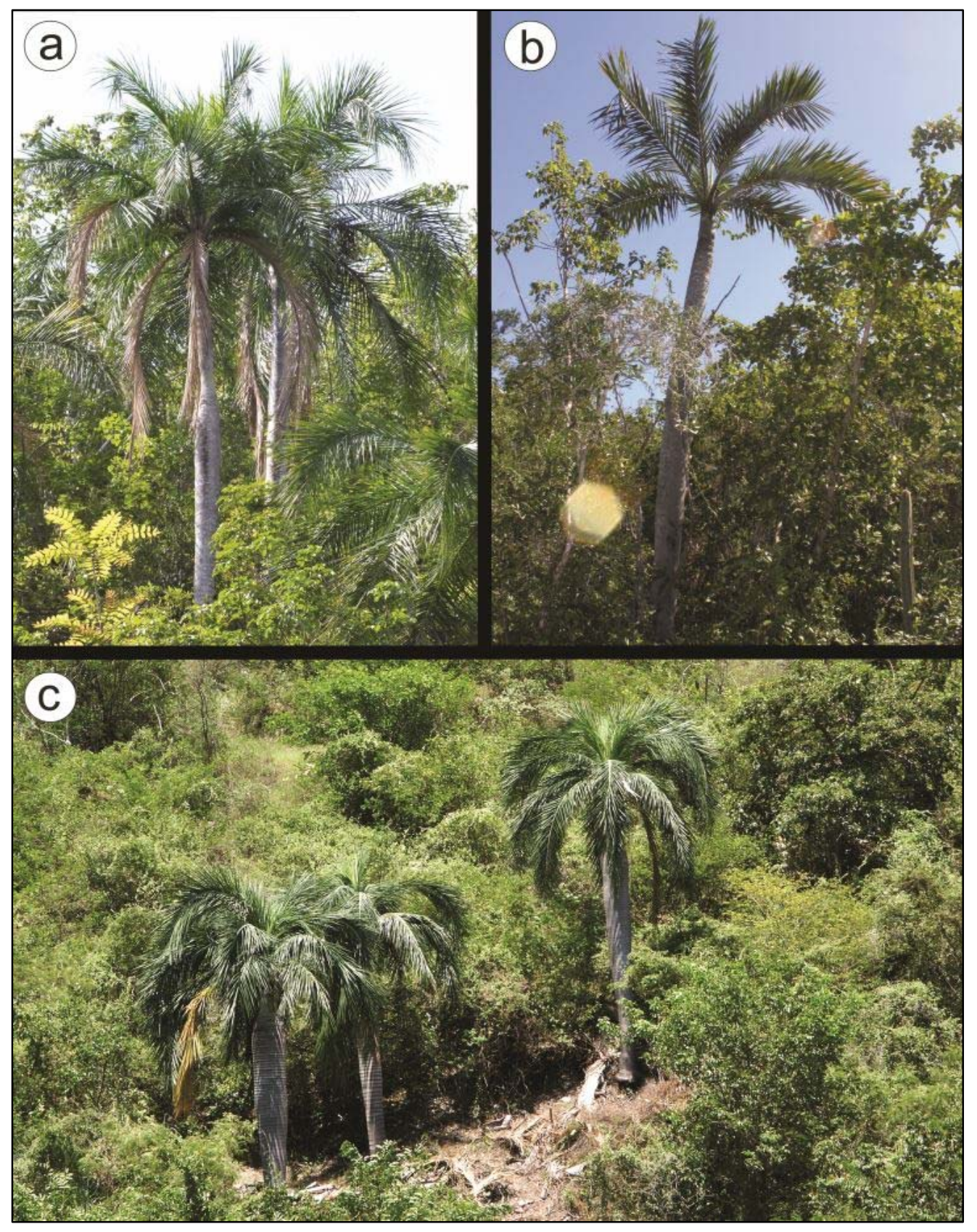

Fig 3.2. Pseudophoenix plants in Dominican Republic and Haiti. a Adult individual of $P$. lediniana, Haiti; b Adult individuals of $P$. sargentii, Dominican Republic; c Adult individuals of $P$. vinifera, Dominican Republic. Images by Rosa Rodríguez $(\mathrm{a}-\mathrm{b})$ and Scott Zona (c). 


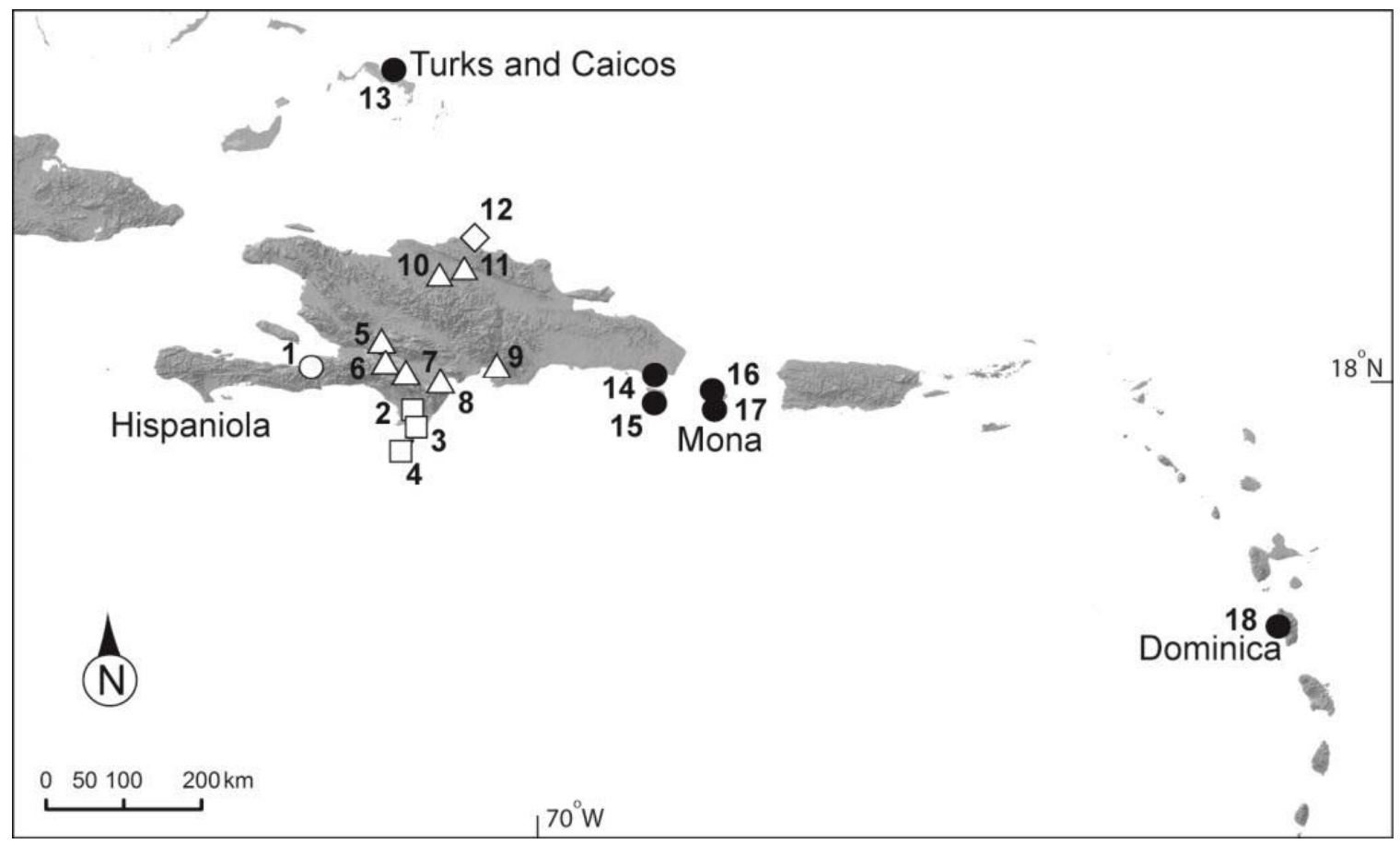

Fig. 3.3. Geographical distribution of the 18 populations of Pseudophoenix included in this study. $\bigcirc=P$. lediniana, $\square=P$. ekmanii, $\triangle=P$. vinifera, $\diamond=P$. sp. Nova, $\bullet=P$. sargentii. 


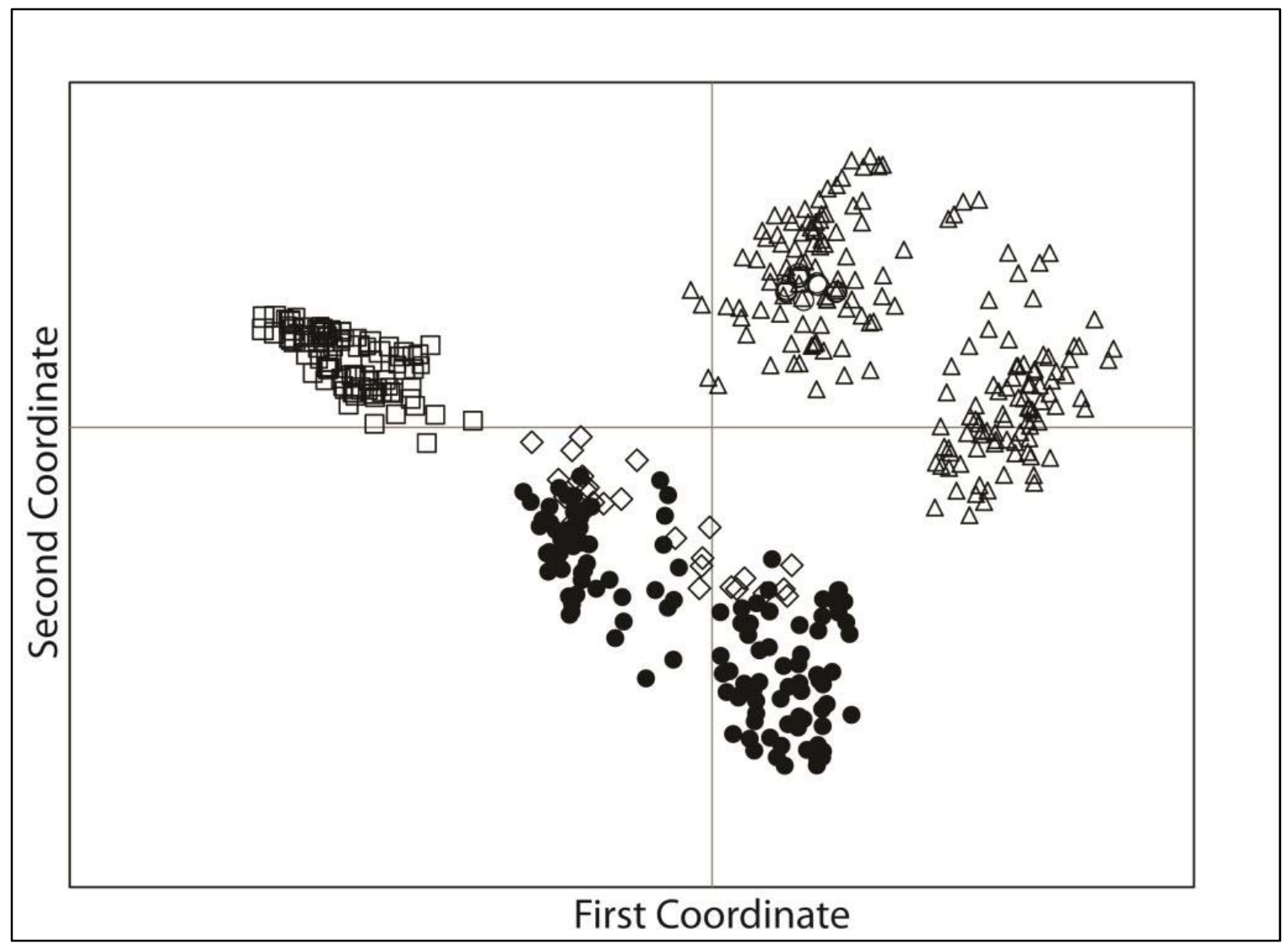

Fig. 3.4. Principal coordinate analysis scatter diagram along the two first coordinates. Based on nine microsatellite for 454 individuals belonging to 18 populations of Pseudophoenix. $\bigcirc=$ P. lediniana, $\square=P$. ekmanii, $\triangle=P$. vinifera, $\diamond=P$. sp. nova, $=P$. sargentii. 


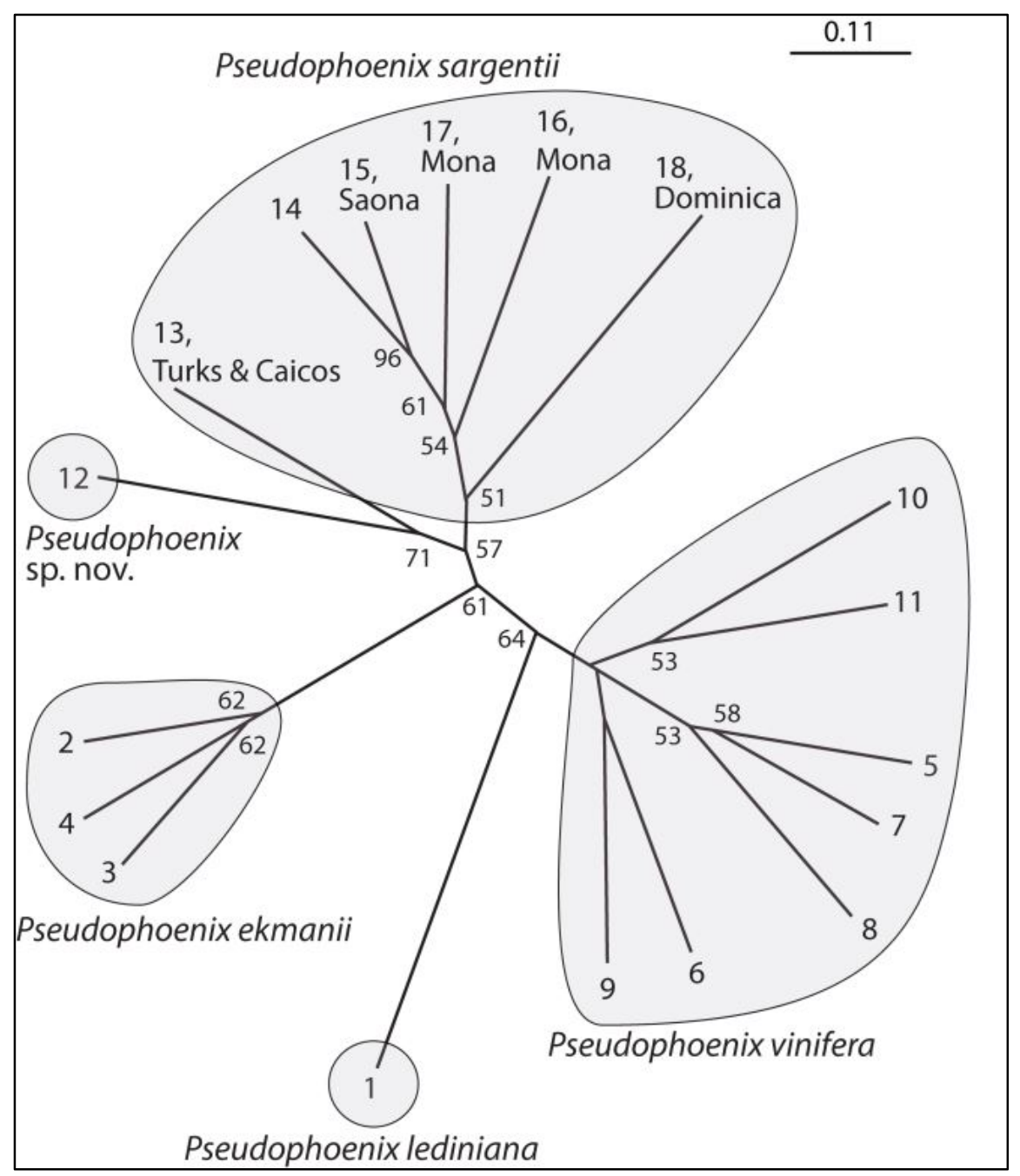

Fig. 3.5. Neighbor joining network (based on chord distance of Cavalli-Scorza and Edwards (1967). It shows the genetic relationships among 18 populations of Pseudophoenix from nine microsatellite loci. Branch lengths are proportional to distances and bootstrap supports for recovered clusters are also indicated. All populations are from Hispaniola except where indicated. 


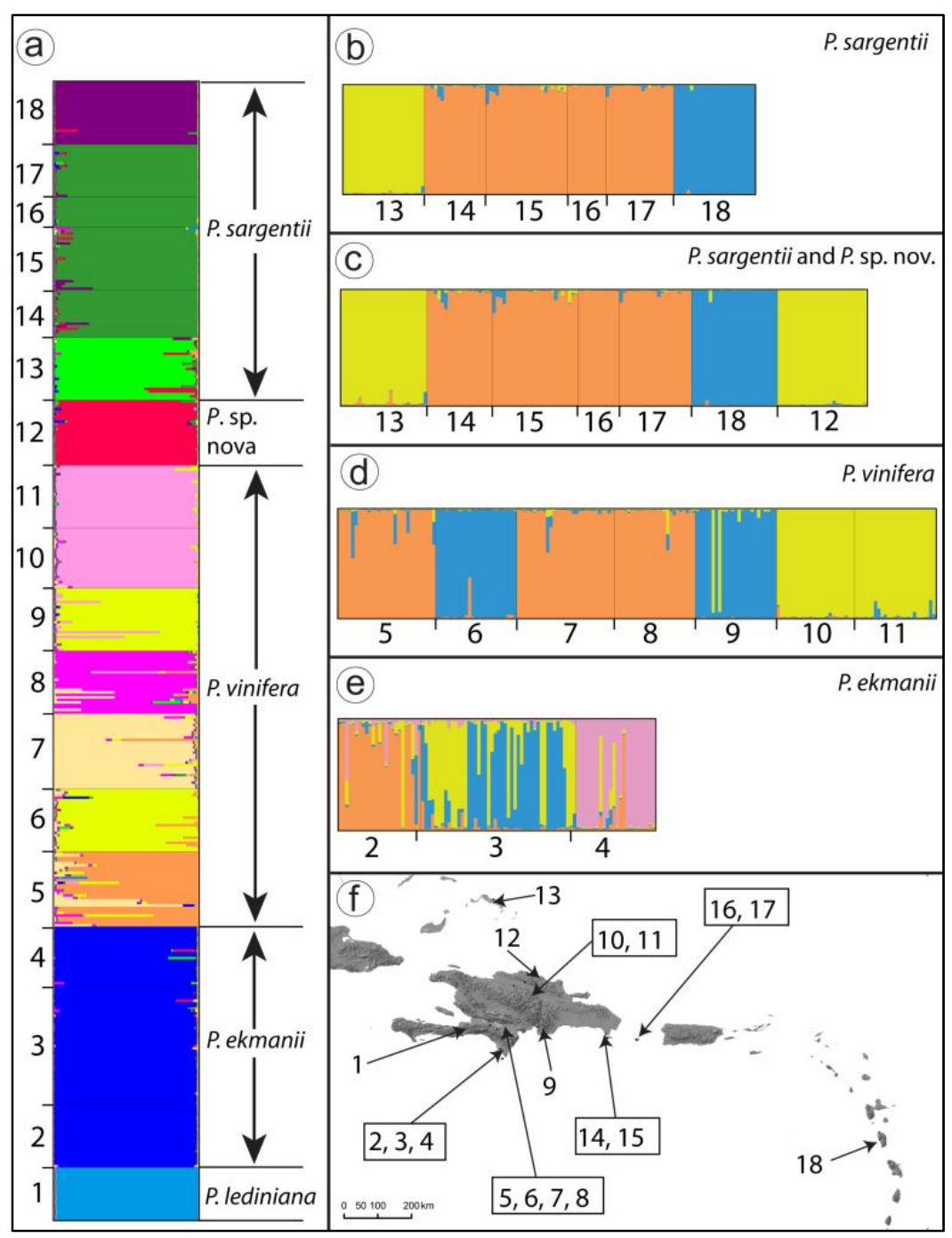

Fig. 3.6. STRUCTURE analyses for individuals from populations of Pseudophoenix. Color and box sizes indicate the cluster type of each individual and the number of plants sampled per population. The vertical lines indicate the probability that each individual belongs to an inferred cluster. a Analysis for the 18 populations included in the study. b-e Analyses of four separate data sets as indicated in each insert. $f$ Geographical distribution of the 18 populations. STRUCTURE analyses for inserts a and e were based on 9 microsatellite loci, for the rest of analyses (inserts $\mathrm{c}$ and e) the data were generated by ten microsatellite loci. 
Table 3.1. Demographic and geographical data of populations of Pseudophoenix.

\begin{tabular}{|c|c|c|c|c|c|}
\hline \multirow{2}{*}{$\begin{array}{l}\text { Species and } \\
\text { population number }\end{array}$} & \multicolumn{4}{|c|}{ Estimate Number of Individuals ${ }^{\mathrm{b}}$} & \multirow[t]{2}{*}{ Protected area } \\
\hline & Seedl. & Juven. & Adul. & Total & \\
\hline \multicolumn{6}{|l|}{ P.lediniana } \\
\hline 1 (Jacmel, HA) & 0 & 2 & 71 & 73 & None \\
\hline \multicolumn{6}{|l|}{ P. ekmanii } \\
\hline 2 (Sabana del Algodón, DR) & 105 & 1,550 & 820 & 2475 & Parque Nacional Jaragua \\
\hline 3 (Trudillé, DR) & 324 & 517 & 205 & 1046 & Parque Nacional Jaragua \\
\hline 4 (Isla Beata, DR) & 59 & 59 & 211 & 329 & Parque Nacional Jaragua \\
\hline \multicolumn{6}{|l|}{ P.vinifera } \\
\hline 5 (Martín Brunito, DR) & 230 & 80 & 300 & 610 & Monumento Natural Las Caobas \\
\hline 6 (Jimaní, DR) & 0 & 160 & 300 & 461 & None \\
\hline 7 (Loma Charco Azul, DR) & 520 & 40 & 350 & 910 & Reserva Biológica Loma Charco Azul \\
\hline 8 (Cabral, DR) & 10 & 36 & 60 & 106 & None \\
\hline 9 (Bahía de Ocoa, DR) & 0 & 4 & 120 & 124 & None \\
\hline 10 (Gurabo, DR) & 300 & 20 & 150 & 470 & None \\
\hline 11 (Esperanza, DR) & 90 & 2 & 60 & 152 & None \\
\hline \multicolumn{6}{|l|}{$P$. sp nova } \\
\hline 12 (Puerto Plata, DR) & 5 & 20 & 9 & 34 & None \\
\hline \multicolumn{6}{|l|}{ P. sargentii } \\
\hline 13 (Montpeller Pond, TC) & 150 & 125 & 50 & 325 & None \\
\hline 14 (Palmilla, DR) & 0 & 69 & 34 & 103 & Parque Nacional del Este \\
\hline 15 (Isla Saona, DR) & 100 & 100 & 37 & 237 & Parque Nacional del Este \\
\hline 16 (Antena, Mona Island) & 2 & 8 & 4 & 14 & National Natural Landmark of Mona \\
\hline 17 (Uvero, Mona Island) & 2 & 0 & 22 & 24 & National Natural Landmark of Mona \\
\hline 18 (Heights of Mero, DO) & 0 & 0 & 70 & 70 & None \\
\hline
\end{tabular}

Table 3.1. Continued. 
${ }^{a}$ Localities and area of origin are given inside the parenthesis. Areas or origin are coded as HA=Haiti, DR $=$ Dominican Republic, $\mathrm{TC}=$ Turks and Caicos Islands, $\mathrm{DO}=$ Dominica. ${ }^{\mathrm{b}}$ Demographic groups are coded as Seedl. $=$ Seedlings, Juven. $=$ Juveniles, Adul. $=$ Adults. $*$ Demographic information derived from Rodriguez (in-press). $* *$ Demographic information derived from Namoff (2011). 
Table 3.2. Pseudophoenix population genetic statistics. Data based on the analyses of 10 loci except for P. ekmanii for which 9 loci were studied.

\begin{tabular}{|c|c|c|c|c|c|c|c|c|c|c|}
\hline $\begin{array}{l}\text { Species and } \\
\text { population }^{\text {a }}\end{array}$ & Origin & $\mathrm{P}$ & $\mathrm{n}_{\mathrm{p}}$ & A & $\mathrm{H}_{\mathrm{o}}$ & $\mathrm{H}_{\mathrm{e}}$ & $\mathrm{n}_{\mathrm{ds}}$ & $\mathrm{F}_{\text {is }}$ & $\mathrm{N}_{\mathrm{ig}}$ & LDL \\
\hline \multicolumn{11}{|l|}{ P. lediniana } \\
\hline $1(21)$ & Haiti & 40 & 3 & 1.7 & 0.25 & 0.50 & 3 & 0.51 & 6 & 4 \\
\hline \multicolumn{11}{|l|}{ P. ekmanii } \\
\hline $2(25)$ & Dominican Republic & 100 & 4 & 3.7 & 0.22 & 0.47 & 7 & 0.55 & 0 & 8 \\
\hline $3(46)$ & Dominican Republic & 100 & 5 & 5.1 & 0.29 & 0.53 & 8 & 0.45 & 0 & 25 \\
\hline $4(25)$ & Dominican Republic & 77 & 3 & 2.6 & 0.20 & 0.44 & 6 & 0.54 & 1 & 33 \\
\hline \multicolumn{11}{|l|}{ P.vinifera } \\
\hline $5(30)$ & Dominican Republic & 100 & 2 & 5 & 0.29 & 0.51 & 7 & 0.43 & 0 & 24 \\
\hline $6(25)$ & Dominican Republic & 100 & 2 & 4.7 & 0.26 & 0.50 & 5 & 0.49 & 0 & 24 \\
\hline $7(30)$ & Dominican Republic & 100 & 2 & 4 & 0.30 & 0.49 & 5 & 0.39 & 0 & 6 \\
\hline $8(25)$ & Dominican Republic & 100 & 4 & 4.6 & 0.31 & 0.50 & 8 & 0.40 & 0 & 6 \\
\hline $9(25)$ & Dominican Republic & 90 & 2 & 3.2 & 0.17 & 0.45 & 7 & 0.63 & 1 & 33 \\
\hline $10(24)$ & Dominican Republic & 100 & 3 & 3.5 & 0.29 & 0.50 & 5 & 0.42 & 0 & 4 \\
\hline $11(25)$ & Dominican Republic & 100 & 2 & 4.8 & 0.34 & 0.55 & 6 & 0.38 & 0 & 29 \\
\hline \multicolumn{11}{|l|}{$P$. sp. nova } \\
\hline $12(26)$ & Dominican Republic & 100 & 4 & 6.3 & 0.36 & 0.66 & 9 & 0.47 & 0 & 33 \\
\hline \multicolumn{11}{|l|}{ P.sargentii } \\
\hline $13(25)$ & Turks and Caicos & 100 & 9 & 8.4 & 0.44 & 0.66 & 8 & 0.34 & 0 & 31 \\
\hline $14(19)$ & Dominican Republic & 100 & 5 & 4.4 & 0.40 & 0.64 & 6 & 0.38 & 0 & 33 \\
\hline $15(25)$ & Dominican Republic & 100 & 4 & 4.8 & 0.40 & 0.62 & 7 & 0.37 & 0 & 24 \\
\hline $16(12)$ & Mona Island & 80 & 3 & 2.1 & 0.15 & 0.43 & 6 & 0.67 & 0 & 6 \\
\hline $17(21)$ & Mona Island & 80 & 3 & 2.1 & 0.20 & 0.40 & 6 & 0.48 & 0 & 4- \\
\hline $18(25)$ & Dominica & 80 & 0 & 2.8 & 0.22 & 0.45 & 6 & 0.52 & 0 & 11 \\
\hline
\end{tabular}


Table 3.2. Continued.

Population genetic statistics are coded as follows: $\mathrm{P}$, percentage of polymorphic loci; $\mathrm{n}_{\mathrm{p}}$, number of private alleles; A, average number of alleles per locus; $\mathrm{H}_{\mathrm{o}}$, observed heterozygosity; $\mathrm{H}_{\mathrm{e}}$, expected heterozygosity; $\mathrm{n}_{\mathrm{ds}}$, number of loci that deviate significantly from HWE $(\mathrm{P}<0.05) ; \mathrm{F}_{\text {is }}$, inbreeding coefficient; $\mathrm{N}_{\mathrm{ig}}$, number of identical genotype pairs; LDL, percentage of paired loci showing linkage disequilibrium. ${ }^{\mathrm{a}}$ Number of sampled individuals are given inside the parenthesis. Notice that all $\mathrm{F}_{\text {is }}$ values deviate significantly from $0(\mathrm{P}<0.05)$. 
Table 3.3. Genetic differentiation and estimates of migration rate for populations of Pseudophoenix. Above diagonal $=\mathrm{D}_{\text {est }}$ estimates. Below diagonal $=\mathrm{N}_{\mathrm{m}}$ values.

\begin{tabular}{|c|c|c|c|c|c|c|c|c|c|c|c|c|c|c|c|c|c|c|}
\hline & 1 & 2 & 3 & 4 & 5 & 6 & 7 & 8 & 9 & 10 & 11 & 12 & 13 & 14 & 15 & 16 & 17 & 18 \\
\hline 1 & & 0.85 & 0.89 & 0.88 & 0.66 & 0.70 & 0.75 & 0.68 & 0.54 & 0.72 & 0.67 & 0.87 & 0.89 & 0.83 & 0.83 & 0.97 & 0.80 & 0.8 \\
\hline 2 & 0.29 & & 0.14 & 0.12 & 0.98 & 0.79 & 0.98 & 0.97 & 0.77 & 0.85 & 0.75 & 0.71 & 0.87 & 0.94 & 0.89 & 0.82 & 0.94 & 0.78 \\
\hline 3 & 0.36 & 2.94 & & 0.15 & 0.95 & 0.78 & 0.96 & 0.95 & 0.78 & 0.84 & 0.71 & 0.76 & 0.73 & 0.79 & 0.80 & 0.68 & 0.83 & 0.74 \\
\hline 4 & 0.2 & 2.54 & 1.65 & & 0.96 & 0.80 & 0.98 & 0.97 & 0.82 & 0.85 & 0.80 & 0.73 & 0.87 & 0.94 & 0.86 & 0.83 & 0.95 & 0.75 \\
\hline 5 & 0.36 & 0.5 & 0.57 & 0.38 & & 0.30 & 0.12 & 0.18 & 0.39 & 0.48 & 0.57 & 0.65 & 0.58 & 0.52 & 0.51 & 0.81 & 0.50 & 0.82 \\
\hline 6 & 0.37 & 0.57 & 0.66 & 0.42 & 1.12 & & 0.23 & 0.50 & 0.14 & 0.62 & 0.37 & 0.6 & 0.64 & 0.90 & 0.82 & 0.82 & 0.89 & 0.75 \\
\hline 7 & 0.34 & 0.48 & 0.55 & 0.37 & 2.48 & 1.11 & & 0.20 & 0.38 & 0.31 & 0.51 & 0.66 & 0.55 & 0.70 & 0.65 & 0.85 & 0.64 & 0.91 \\
\hline 8 & 0.36 & 0.52 & 0.6 & 0.4 & 2.04 & 0.84 & 1.72 & & 0.54 & 0.45 & 0.64 & 0.73 & 0.60 & 0.55 & 0.51 & 0.85 & 0.49 & 0.79 \\
\hline 9 & 0.31 & 0.43 & 0.51 & 0.31 & 0.75 & 1.61 & 0.69 & 0.62 & & 0.41 & 0.21 & 0.67 & 0.71 & 0.89 & 0.83 & 0.84 & 0.90 & 0.69 \\
\hline 10 & 0.36 & 0.56 & 0.65 & 0.42 & 1.01 & 0.77 & 1.29 & 1.13 & 0.7 & & 0.31 & 0.72 & 0.68 & 0.81 & 0.65 & 0.75 & 0.77 & 0.78 \\
\hline 11 & 0.41 & 0.62 & 0.73 & 0.46 & 0.87 & 1.16 & 0.8 & 0.77 & 1.2 & 1.37 & & 0.73 & 0.72 & 0.91 & 0.77 & 0.84 & 0.86 & 0.78 \\
\hline 12 & 0.41 & 0.86 & 0.94 & 0.66 & 0.86 & 0.83 & 0.81 & 0.84 & 0.6 & 0.84 & 0.86 & & 0.32 & 0.44 & 0.50 & 0.6 & 0.51 & 0.59 \\
\hline 13 & 0.42 & 0.78 & 1.01 & 0.58 & 0.97 & 0.84 & 0.92 & 1.01 & 0.6 & 1 & 0.93 & 2.69 & & 0.36 & 0.33 & 0.45 & 0.35 & 0.69 \\
\hline 14 & 0.38 & 0.69 & 0.87 & 0.5 & 1.03 & 0.73 & 0.85 & 1 & 0.54 & 0.82 & 0.77 & 1.87 & 2.72 & & 0.05 & 0.24 & 0.10 & 0.41 \\
\hline 15 & 0.39 & 0.72 & 0.89 & 0.56 & 1.01 & 0.77 & 0.86 & 1.01 & 0.56 & 0.94 & 0.86 & 1.56 & 2.28 & 8.55 & & 0.21 & 0.13 & 0.36 \\
\hline 16 & 0.2 & 0.45 & 0.61 & 0.3 & 0.49 & 0.46 & 0.46 & 0.5 & 0.33 & 0.49 & 0.5 & 0.83 & 1.15 & 1.66 & 1.61 & & 0.34 & 0.48 \\
\hline 17 & 0.2 & 0.37 & 0.46 & 0.26 & 0.56 & 0.39 & 0.47 & 0.56 & 0.29 & 0.46 & 0.43 & 0.75 & 1.07 & 2.07 & 2.11 & 0.62 & & 0.36 \\
\hline 18 & 0.23 & 0.5 & 0.62 & 0.37 & 0.44 & 0.5 & 0.42 & 0.46 & 0.38 & 0.51 & 0.53 & 0.81 & 0.77 & 0.94 & 1.03 & 0.54 & 0.46 & \\
\hline
\end{tabular}

